\title{
Rice straw ash: A potential pozzolanic supplementary material for cementing systems
}

\author{
Josefa Rosellóa $^{a}$ Lourdes Soriano $^{b}$, M. Pilar Santamarina ${ }^{a}$, Jorge L. Akasaki ${ }^{c}$, José Monzób $^{b}$, \\ Jordi Payáb,* \\ a Departamento de Ecosistemas Agroforestales, Universitat Politècnica de València, Spain \\ ${ }^{\mathrm{b}}$ Instituto de Ciencia y Tecnología del Hormigón ICITECH, Universitat Politècnica de València, Spain \\ c Departamento de Engenharia Civil, Universidade Estadual Paulista Campus Ilha Solteira, Brazil
}

\section{A R T I C L E I N F O}

\section{Article history:}

Received 11 October 2016

Received in revised form 9 March 2017

Accepted 21 March 2017

Available online 1 April 2017

\section{Keywords:}

Rice straw ash

FESEM

Spodogram

Chemical composition

Amorphous silica

Pozzolanic reactivity

\begin{abstract}
A B S T R A C T
Biomass waste from rice straw has many management problems, including field firing causing severe air pollution and natural organic decomposition resulting in methane emission. The conversion of this waste to ashes may offer the possibility of reusing them in cementing systems. For the first time ashes from different parts of the rice plant (Oryza sativa) were characterised from the chemical composition point of view: rice leaf ash (RLA), rice leaf sheath ash (RlsA) and rice stem ash (RsA). Microscopic studies on ashes revealed heterogeneity in the distribution of chemical elements in the remaining cellular structure (spodograms). The highest concentration of $\mathrm{SiO}_{2}$ was found in dumbbell-shaped phytoliths $\left(\% \mathrm{SiO}_{2}>78 \%\right.$ ). In the global chemical composition of ashes, $\mathrm{SiO}_{2}$ was also the main oxide present. According to Vassilev's classification of chemical composition, RLA belongs to the K-MA zone (medium acid), RlsA to the K-zone (low acid) and RsA to the S-zone (high acid). Calcination temperatures $\geq 550^{\circ} \mathrm{C}$ completely removed organic matter from the straw and ashes underwent significant sinterisation by calcining at $650{ }^{\circ} \mathrm{C}$ due to the presence of potassium chloride. Here, ashes from global straw (rice straw ash, RSA) are characterised (via X-ray diffraction, Fourier transform infrared spectroscopy and thermogravimetry) and tested from a reactivity point of view (reaction towards calcium hydroxide) in order to assess the possibility for its reuse in cementing systems. Results from pastes made by mixing RSA and calcium hydroxide showed that the pozzolanic reactivity of the ashes is important (hydrated lime fixation of $82 \%$ for 7 days and $87 \%$ for 28 days in RSA:hydrated lime paste) and cementing C $-\mathrm{S}-\mathrm{H}$ gel is formed after 7 and 28 days at room temperature. Compressive strength development of Portland cement mortars with 10\% and 25\% replacements by RSA yielded $107 \%$ and $98 \%$ of the strength of control mortar after 28 days of curing. Frattini test confirmed the pozzolanicity of the RSA blended cements. These reactivity results are very promising in terms of the potential reuse of ashes in cementing systems.
\end{abstract}

(C) 2017 Elsevier B.V. All rights reserved.
Abbreviations: AWA, agricultural waste ashes; BLA, Bamboo leaf ash; $\mathrm{CH}$, calcium hydroxide (hydrated lime); $\mathrm{C}-\mathrm{S}-\mathrm{H}$, calcium silicate hydrate gel; DTG, derivative thermogravimetric curves; EDS, energy dispersive X-ray spectroscopy; FESEM, field emission scanning electron microscopy; FTIR, Fourier transform infrared spectroscopy; OM, optical microscopy; RHA, rice husk ash; RLA, rice leaf ash; RlsA, rice leaf sheath ash; RsA, rice stem ash; RSA, rice straw ash; SCM, supplementary cementing material; SLA, sugarcane leaf ash; TG, thermogravimetry; XRD, X-ray powder diffraction.

* Corresponding author.

E-mail addresses: jrosello@upvnet.upv.es (J. Roselló), lousomar@upvnet.upv.es (L. Soriano), mpsantam@eaf.upv.es (M.P. Santamarina), akasaki@dec.feis.unesp.br (J.L. Akasaki),jmmonzo@cst.upv.es (J. Monzó), jjpaya@cst.upv.es (J. Payá).

\section{Introduction}

Agricultural wastes are commonly assessed as biomass sources for energy purposes. They can be classified in three groups: energy crops, food production wastes and agricultural wastes (Titiloye et al., 2013). Agricultural wastes are usually composed of straws (leaves and stems) and fruit-shells. Some industrially derived agricultural wastes also include bagasse, cobs, seeds, pods and husks. Huge amounts of these wastes are available and the selection and appropriate treatments of them could provide building and infrastructure materials.

One of the most important challenges related to the production of building materials is focused on their environmental impact (ecological footprint, carbon footprint), mainly on the production of 
inorganic binders, such as ordinary Portland cement OPC (Barceló et al., 2014). It is well known than the production of OPC is a very intensive process both in terms of energy and raw materials. About $5 \%$ of total worldwide anthropogenic $\mathrm{CO}_{2}$ emissions are generated from the manufacture of OPC-based cement products (Worrell et al., 2001). Cement production has rapidly increased over the last few decades and reached annual production of 4.3 billion tonnes in 2014 (CEMBUREAU, 2014). Since 1990, the blending compositions of cements have changed significantly (Schneider et al., 2011), which has involved a reduction in clinker content (also named the Clinker factor, CF). The CF value in 2003 was 0.85 , whereas in 2010 it was 0.77; the prediction for 2050 is for it to be 0.71 (WBCSD, 2009). This reduction in CF was due to the use of supplementary cementing materials (SCMs). Traditionally (Siddique and Khan, 2011), wastes from industrial activities are blended with Portland cement clinker: ground granulated blast furnace slag, coal fly ash and silica fumes. The first ash from agricultural biomass used in cement or concrete was rice husk ash (RHA) (Mehta, 1983). Utilisation of ashes will contribute to the sustainability of biomass for power generation. Valorisation of bottom ashes, fly ashes and fluidised bed ashes can be carried out by bulk optimisation options: fertiliser and soil amendment, component of building materials or, in the case of carbon-rich ashes, reuse as fuel (Pels and Sarabèr, 2011).

Over the last few decades, greater interest on the development of new SCM derived from agricultural wastes (biomass) is observed in the scientific literature; although the commercialisation of agricultural waste ashes (AWA) and its application in building materials is still scarce (Aprianti et al., 2015). Moreover, in the last years interest has increased regarding the reuse of some biomass-derived ashes in geopolymers (alkali activated materials) to partially replace the inorganic precursor (Moraes et al., 2016) or totally replace the sodium silicate in the alkaline activator (Bouzón et al., 2014). In both cases, reactive silica in the ashes plays an important role for the development of high-performance geopolymers.

The main basis for the valorisation of these AWA lies in the fact that they contain high amounts of silica. This silica is a basic component required for a pozzolanic reaction. This reaction consists of the acid-base reaction between calcium hydroxide (portlandite, when produced from hydration of Portland cement) and silicon oxide (silica):

$\mathrm{Ca}(\mathrm{OH})_{2}+\mathrm{SiO}_{2} \rightarrow \mathrm{C}-\mathrm{S}-\mathrm{H}($ gel $)$

The chemical reaction yields calcium silicate hydrate gel $(\mathrm{C}-\mathrm{S}-\mathrm{H})$, which has cementing properties. When a SCM presents this behaviour, it is termed a pozzolan and it presents pozzolanic properties. The presence of silica in ash is a necessary factor for a pozzolanic reaction, although it is not the only required factor: a small size of ash particle (high specific surface area) and amorphous state (not crystalline phase) are also required. In some cases, amorphous alumina is also involved in the pozzolanic process.

Over the last few years, interest has increased regarding the study the valorisation of AWA (Vassilev et al., 2013; Pels and Sarabèr, 2011), specifically on the addition of AWA to cements (blended Portland cements, alkali-activated cements) and concrete for the following reasons: (a) biomass is produced worldwide in huge amounts and frequently its management is very complicated; (b) valorisation as livestock food, fertiliser, cellulosic-based derived materials (fibres, boards) are not always available or are not economically viable; (c) energetic valorisation of biomass gained interest as a substitute for fossil fuels since it is technically viable worldwide; (d) the transformation of biomass into AWA is an $\mathrm{CO}_{2}$ neutral process because the carbon released to the atmosphere during combustion was recently fixed by photosynthesis; (e) the ashes could show pozzolanic properties and be then valorised in building materials and (f) the construction industry has the capacity to take in these ashes due to its large requirements in terms of raw materials.

Recently, some advances in the application of new AWA in cementing systems were reported, including: ashes from banana leafs (Musa sp., Kanning et al., 2014), switchgrass (Panicum virgatum) (Wang et al., 2014), elephant grass (Pennisetum purpureum, Cordeiro and Sales, 2015), bamboo leaf (Bambusa sp., Frías et al., 2012), sugarcane straw (Saccharum officinarum, Moraes et al., 2015), barley straw (Hordeum vulgare, Cobreros et al., 2015) and plane tree (Platanus sp., Binici et al., 2008).

Rice straw is an agricultural waste that has some management problems: field firing causes severe air pollution and natural organic decomposition favours methane emission (Yuan et al., 2014). This last process has a potent environmental effect in terms of greenhouse gas emission, as the global warming potential of methane is much higher than that of $\mathrm{CO}_{2}$ : 25-times more for a 100-year horizon and 72-times more for 20-year horizon (IPCC, 2007). Thus, it is crucial to valorise this waste as rice production accounts for $5-10 \%$ of worldwide methane emissions. Huge amounts of rice straw are produced worldwide, considering that $1-1.5 \mathrm{~kg}$ of straw is generated for every $1 \mathrm{~kg}$ of paddy rice (Binod et al., 2010). The worldwide production of rice straw was 731 million tonnes in 2008 (Abdel-Rahman et al., 2015) and Asia was the major producer, generating 620 million tonnes of the straw (IRRI, 2016). However, scarce research exists on the characterisation of ashes from rice straw ash (RSA) and their potential applications. An interesting approach for obtaining pure silica from rice straw by a sono-assisted sulphuric acid process was reported (Rehman et al., 2013) and Abou-Sekkina et al. (2010) studied three samples of RSA from Egypt and concluded that the silica content was 65\% by mass and that no crystalline phases were identified. Ataie et al. (2015) prepared ashes from rice straw and wheat straw after previous treatment with hydrochloric acid and further calcination at $650^{\circ} \mathrm{C}$ and $500^{\circ} \mathrm{C}$.

It is well-known that silicon is an element absorbed by the roots of plants in the form of silicic acid, which is transported through the vascular system and deposited in the form of opal or hydrated amorphous silica $\left(\mathrm{SiO}_{2} \cdot n \mathrm{H}_{2} \mathrm{O}\right)$. This silica compound is deposited in: (a) the cellular walls; (b) the interior of the cells (lumen); (c) epidermal appendages (trichomes) and (d) the intercellular spaces in stems and leaves (Prychid et al., 2003). This precipitation process of silica is irreversible (Epstein, 1999): in the three first cases a silica particle replicates the shape of the cellular structure, while for the fourth case no relationship between silica deposit shape and the intercellular space is obtained.

Monocot plants accumulate silica ( $>3 \mathrm{mg}$ of Si per $\mathrm{g}$ of dried matter), mainly plants belonging to Poaceae family: rice (Oryza sativa) and sugarcane (Saccharum officinarum) (Ma and Yamaji, 2006). Epidermal tissues in Poaceae species present particular characteristics that are used in taxonomy. Some taxonomic classifications are based on these cellular dispositions: siliceous cells (phytoliths), suberous cells and trichomes. Phytoliths are solid deposits in which silica is the main component. Their size (typically $10-20 \mu \mathrm{m}$ ) and their shape vary significantly depending on the plant. The following main morphotypes are described: dumbbells, saddle and cross; also intermediate shapes can be found (Wilding and Drees, 1971; Piperno, 2006).

In the rice plant, the silica is highly concentrated in the husk (more than $20 \%$ by mass of dried husk). Leaves (formed by leaf blades and leaf sheaths) also are silica-rich parts and contain $13 \%$ and $12 \%$ silica, respectively. Finally, roots store less silica (2\%)(Anala and Nambisan, 2015).

The goal of this paper is to characterise different parts of the rice plant (Oryza sativa) by means of the identification and analysis of 

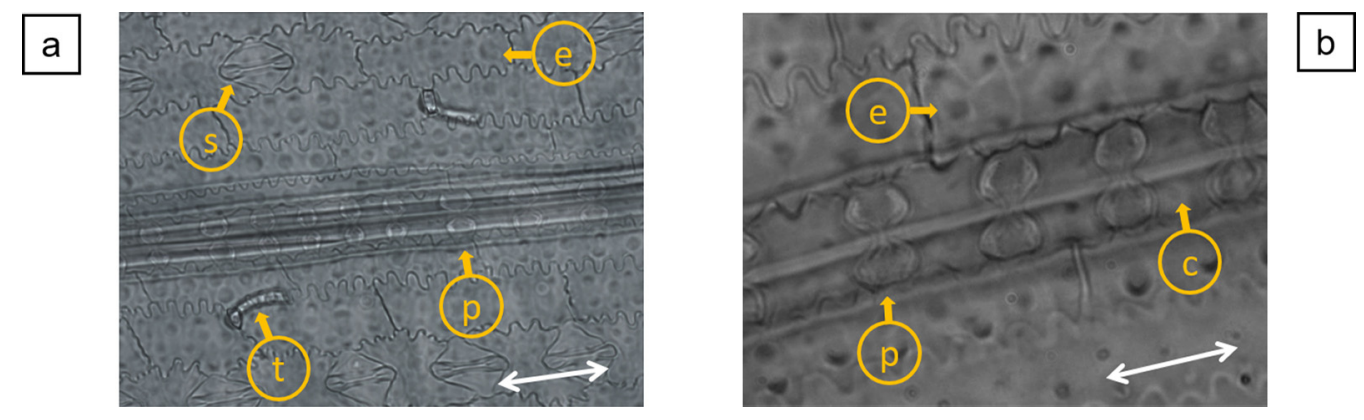

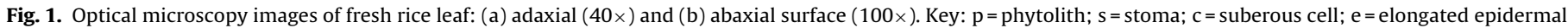
cell; $\mathrm{t}=$ trichome; arrows indicate the longitudinal direction of the leaf.

the distribution of chemical elements present in the ash (energy dispersive X-ray spectroscopy, EDS) assessed in terms of the obtained spodogram (optical and field emission scanning electron microscopy), crystalline pattern (X-ray powder diffraction, XRD) and reactivity towards calcium hydroxide (pozzolanic reactivity, reaction products characterisation and hydrated lime fixation) and towards ordinary Portland cement (compressive strength and Frattini test).

\section{Materials and methods}

Rice straw samples (leaf blade, leaf sheath and stem) were collected in L'Albufera (Valencia, Spain). These samples were stored at $4{ }^{\circ} \mathrm{C}$ in sealed plastic bags until they were used for the analyses.

Fresh rice straw samples were washed thoroughly to remove residual soil contamination. One squared centimetre sections were prepared by cutting and paradermal lamellae $40 \mu \mathrm{m}$ thick were prepared using a freezing microtome (Jung AG). These cuts were clarified with a $50 \%$ sodium hypochlorite solution and then washed several times with distilled water. Small pieces of rice leaves were heated at $105^{\circ} \mathrm{C}$ for $24 \mathrm{~h}$ in a laboratory oven (Memmert UN model) for the studies on dried samples. For studies on calcined samples, fresh pieces of leaf blade, leaf sheath and stem were calcined for $1 \mathrm{~h}$ at different selected temperatures $\left(450,550\right.$ and $\left.650^{\circ} \mathrm{C}\right)$ in a muffle furnace (Carbolite RHF model 1500). The obtained ashes were: rice leaf ash (RLA), rice leaf sheath ash (RlsA) and rice stem ash (RsA). Furthermore, large samples $(20 \mathrm{~g}$ ) of rice straw were calcined at the same temperatures as above to obtain ashes (RSA), which were used for reactivity studies.

For optical microscopy (OM) studies the cuts of fresh material, once clarified, were stained with safranin-light green, dehydrated and mounted using a synthetic mix of resins (Eukit, Mounting medium for microscope preparation) for observation under a light microscope (Olympus PM-10AK3).

For the field emission scanning electron microscopy (FESEM) selected samples (dried rice leaves and ashes) were studied using a ZEISS ULTRA 55 microscope. Samples were studied at $1 \mathrm{kV}$ and at a working distance of 3-5 mm. Samples for chemical microanalysis (EDS) were not covered and were studied at $15 \mathrm{kV}$ at working distance of 5-7 mm.

For reactivity studies, the following equipment was used: Thermogravimetric analysis was performed using a Mettler-Toledo TGA850 instrument. Analysis performed on ashes was carried out in a temperature range of $35-1000^{\circ} \mathrm{C}$ at a heating rate of $20^{\circ} \mathrm{C} \mathrm{min}-1$ in a dried air atmosphere $\left(75 \mathrm{~mL} \mathrm{~min}^{-1}\right.$ gas flow $)$ in $70 \mu \mathrm{L}$ alumina crucibles. Analysis performed on ash:calcium hydroxide pastes was carried out in a temperature range of $35-600^{\circ} \mathrm{C}$ at a heating rate of $10^{\circ} \mathrm{C} \mathrm{min}^{-1}$ in a nitrogen atmosphere $\left(75 \mathrm{~mL} \mathrm{~min}^{-1}\right.$ gas flow) in sealed $100 \mu \mathrm{L}$ pin-holed aluminium crucibles. Fourier transform infrared spectroscopy (FTIR) was performed using a Bruker TENSOR 27 in the wavenumber range between 400 and $4000 \mathrm{~cm}^{-1}$. XRD patterns were obtained by a Bruker AXS D8 Advance with a voltage of $40 \mathrm{kV}$, current intensity of $20 \mathrm{~mA}$ and a Bragg's angle $(2 \theta)$ in the range of $10-60^{\circ}$.

EDS chemical composition results were submitted to variance analysis (ANOVA) with significant values at $P<0.05$. Data analysis was performed using Statgraphics Centurion XVI.II.

Mortars were prepared according to UNE-EN 196-1 standard: water/cement ratio was 0.5 and sand/cement ratio was 3. Prismatic specimens $(40 \times 40 \times 160 \mathrm{~mm})$ were cast, and after demoulding they were cured under water for 7 and 28 days. Control mortar was prepared by using ordinary Portland cement (OPC), Spanish cement CEM I-52.5R. RSA containing mortars were prepared by replacing $10 \%$ and $25 \%$ of OPC by RSA. The ash was previously ground and its mean particle diameter was $13 \mu \mathrm{m}$. Compressive strength values of mortars were obtained by means a universal testing machine according to UNE-EN 196-1. Pozzolanicity studies (Frattini test) were carried out according to UNE-EN 196-5.

\section{Results and discussion}

The rice straw is a mixture of different parts of the rice plant and usually contains leaf blades, leaf sheaths and stems. The easiest part to study using microscopy is the leaf blade, as it is thinner (from herein, we refer to leaf blade as 'leaf'). When calcining leaf, the spodogram is maintained and different parts of the cells and structures can be identified. This is why the first analyses were conducted on the rice leaf and the ashes obtained after the various temperature treatments. Ashes obtained from leaf sheaths and stems will be discussed later in the manuscript. Finally, an approach to reactivity studies from the pozzolanic point of view will be discussed using ash produced from a mixture of the different parts in the straw.

\subsection{Microscopic studies on fresh leaves}

Optical microscopy studies on fresh rice leaves were carried out in order to understand the character of cells in the tissue. The upper (adaxial) and the lower leaf surfaces (abaxial) were analysed. In the adaxial surface image (Fig. 1a) trichomes and phytoliths were easily identified. The phytolits showed a bilobated shape and the major axis of the phytoliths was perpendicular (Fig. 1b) to the longitudinal axis of the leaf (bambusoide dermotype (Prat, 1936)). Phytoliths are arranged short distances from each other and among them suberous cells are disposed. Elongated epidermal cells and stomata are displayed surrounding the aligned phytoliths and suberous cells.

\subsection{Microscopic studies on dried leaves}

Some leaves were dried at $105^{\circ} \mathrm{C}$ for FESEM studies (Fig. 2). In these conditions, free water was released and organic and inorganic structures were maintained in their original arrangements. 

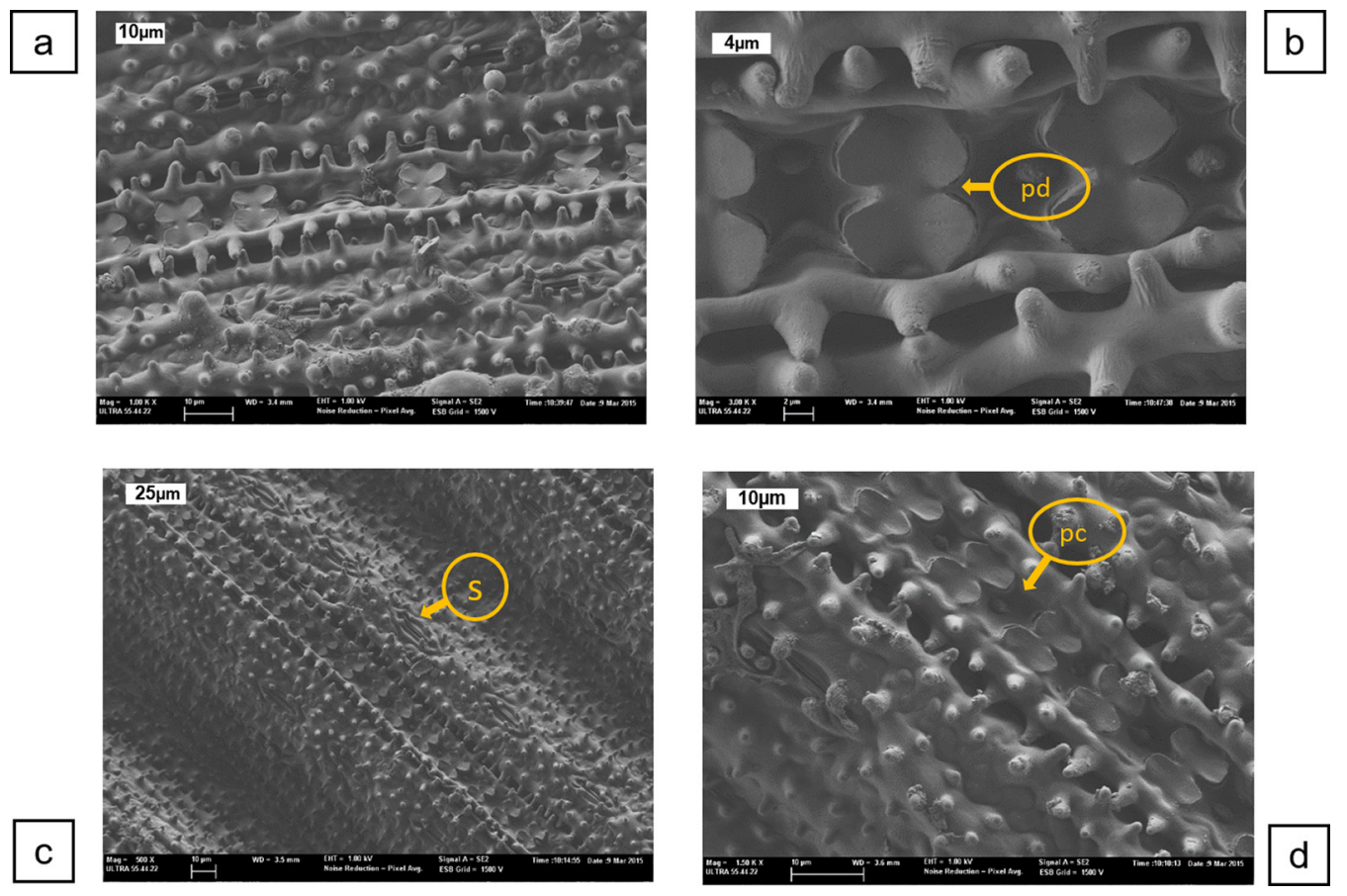

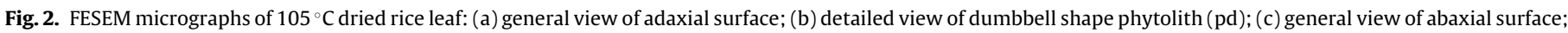
(d) detailed view of cross shape phytolith (pc).

Both surfaces (Fig. 2a and b, adaxial; and Fig. 2c and d, abaxial) presented the same type of epidermal cells and structures. After the drying process, the shape of phytoliths was revealed: some of them seemed to be dumbbell shape (Fig. 2b and d). Apparently, the shape of phytoliths is not homogeneous within the leaf (some appear as a cross shape). Stomata appeared aligned in parallel to the phytoliths arrangement. Abaxial surface showed a wavier form.

\subsection{Microscopies studies on calcined leaves}

Calcination of leaves was carried out to remove organic components. Thus, the spodogram (structural residue resulting from the removal of organic matter by burning, which maintains the leaf's structure) was clearly observed. Samples of leaves were calcined at different temperatures, $450,550,600$ and $650^{\circ} \mathrm{C}$, for $1 \mathrm{~h}$. Then, they were studied by FESEM. Samples obtained at 450,550 and $650^{\circ} \mathrm{C}$ were also assessed by EDS.

Fig. 3 shows some micrographs corresponding to samples calcined at $450^{\circ} \mathrm{C}$. It can be noted than some parts of the leaf maintained a similar structure to the dried samples: the spodogram at $450{ }^{\circ} \mathrm{C}$ maintained the original arrangement. Thus, aligned phytoliths are surrounded with an inorganic matrix (Fig. 3a and b) and stomata are arranged parallel to phytoliths (Fig. 3a). However, the original structure is not maintained for other parts of the leaf, as can be seen in Fig. 3c. Only phytolith chains were unaltered. In Fig. 3d, a detailed view of some phytoliths is shown, in which their dumbbell shape is highlighted. The removal of organic matter rendered the real shape for the phytoliths. Some EDS analysis (spots) were carried out in order to compare the chemical composition of the ashes. Table 1 summarises the chemical composition (in oxide form, by mass) for four selected spots (two phytoliths and two matrix spots). It is very noticeable that phytoliths are mainly formed of $\mathrm{SiO}_{2}$ and $\mathrm{K}_{2} \mathrm{O}$ (more than 90\%) and the surrounding matrix presents more elements in significant percentages: $\mathrm{Cl}, \mathrm{P}_{2} \mathrm{O}_{5}, \mathrm{SO}_{3}, \mathrm{CaO}$ and $\mathrm{MgO}$. $\mathrm{SiO}_{2}$ in the matrix was less than half that value found in phytoliths, while $\mathrm{K}_{2} \mathrm{O}$ increased by twofold. These results reflect the heterogeneity in the disposition of inorganic elements in the ash. Thus, recording 15 EDS signals from $10,000 \mu \mathrm{m}^{2}$ areas, on both abaxial and adaxial surfaces, carried out a general analysis. The mean composition results are summarised in Table 2. Chemical compositions of each area analysed were different and this behaviour is reflected in the standard deviation values for oxide contents. The mean values for the main oxides were: $38.0 \%$ and $43.4 \% \mathrm{SiO}_{2}$ for adaxial and abaxial surfaces and $28.1 \%$ and $27.0 \%$ for $\mathrm{K}_{2} \mathrm{O}$. From the statistical analysis (comparison of mean values from two populations, that is adaxial and abaxial surfaces), it can be concluded that all compound contents are not significantly different, except for chloride and $\mathrm{Na}_{2} \mathrm{O}(P<0.05)$.

The chemical composition of the RLA was similar to that found for sugarcane leaf ash (SLA) calcined at the same temperature (Roselló et al., 2015). In this case, the $\mathrm{SiO}_{2}$ content was higher (mean value of $40.7 \%$ for RLA vs $30.0 \%$ for SLA); $\mathrm{K}_{2} \mathrm{O}$ content was similar $(27.5 \%$ vs $29.0 \%$, respectively). The most important difference is in the chloride content, which was much lower for RLA than in SLA (1.0\% vs $4.0 \%$, respectively). This fact becomes crucial for applications in cements and concrete (Angst et al., 2009) because the presence of chloride ions favours the corrosion of steel in reinforced concrete; thus, RLA will be better in terms of corrosion behaviour. Regarding other elements, RLA presented lower contents of alkaline earth oxides ( $\mathrm{CaO}$ and $\mathrm{MgO})$ and higher in $\mathrm{P}_{2} \mathrm{O}_{5}$. The $\mathrm{SO}_{3}$ contents were similar for both RLA and SLA.

Vassilev et al. (2010) proposed a classification of biomass ashes according to the chemical composition (Fig. 4). Thus, they designed a ternary diagram in which the corners were occupied by the sum of selected oxide contents: (a) the sum of silicon, aluminium, iron, sodium and titanium oxides (this will be referred to as $\sigma$ in this manuscript); (b) the sum of calcium, magnesium and manganese oxides $(\tau)$ and $(\mathrm{c})$ the sum of potassium, phosphorus, sulphur and chlorine oxides ( $\kappa)$. In this way, seven zones were defined, depending on the proportion of these groups of oxides in the ash. Rice husk ash (RHA) is a typically siliceous ash, with very low content of other oxides and consequently is represented in the S-type ash zone. Bamboo leaf ash (BLA) is also located in the S-type zone, as it has similar composition, although it is richer in potassium. Biomass 

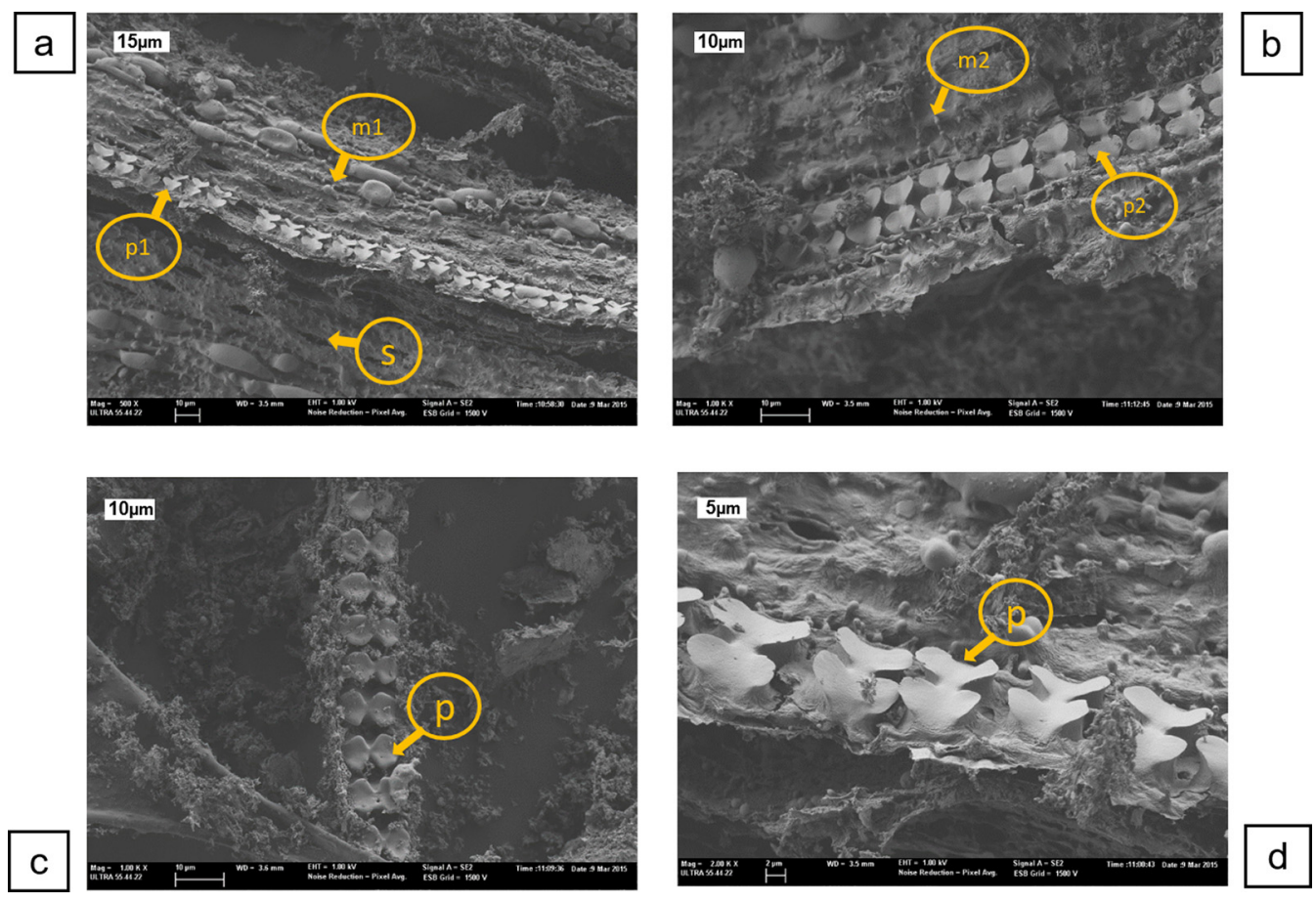

Fig. 3. FESEM micrographs for rice leaf calcined at $450^{\circ} \mathrm{C}$. Key: $\mathrm{p}=$ phytolith; $\mathrm{m}=$ matrix; $\mathrm{p} 1$ and $\mathrm{p} 2$, phytolith spots; $\mathrm{m} 1$ and $\mathrm{m} 2$, matrix spots (see Table 2 ).

Table 1

Spot chemical compositions (EDS, \% by mass) for rice leaf ash obtained at $450^{\circ} \mathrm{C}$ (spots identified in Fig. 3).

\begin{tabular}{llllllrrr}
\hline Spot analysis & $\mathrm{SiO}_{2}$ & $\mathrm{~K}_{2} \mathrm{O}$ & $\mathrm{Cl}$ & $\mathrm{CaO}$ & $\mathrm{MgO}$ & $\mathrm{P}_{2} \mathrm{O}_{5}$ & $\mathrm{SO}_{3}$ & $\mathrm{Na}_{2} \mathrm{O}$ \\
\hline Phytolith 1 (Fig. 3a) & 86.2 & 8.4 & 1.0 & 0.1 & 0.8 & 1.6 & 0.7 & 1.3 \\
Matrix 1 (Fig. 3a) & 40.0 & 23.8 & 6.7 & 4.0 & 4.6 & 1.8 & 1.7 & 2.0 \\
Phytolith 2 (Fig. 3b) & 78.2 & 11.8 & 1.9 & 1.2 & 6.2 & 2.0 & 2.0 \\
Matrix 2 (Fig. 3b) & 25.8 & 27.4 & 5.8 & 11.3 & 6.7 & 10.3 & 10.8 \\
\hline
\end{tabular}

Table 2

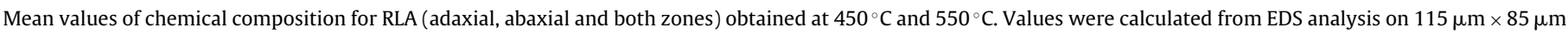
area.

\begin{tabular}{|c|c|c|c|c|c|c|c|c|c|}
\hline Sample & Parameter & $\mathrm{SiO}_{2}$ & $\mathrm{~K}_{2} \mathrm{O}$ & $\mathrm{Cl}$ & $\mathrm{CaO}$ & $\mathrm{MgO}$ & $\mathrm{P}_{2} \mathrm{O}_{5}$ & $\mathrm{SO}_{3}$ & $\mathrm{Na}_{2} \mathrm{O}$ \\
\hline \multirow{4}{*}{$\begin{array}{l}\text { RLA } 450^{\circ} \mathrm{C} \\
\operatorname{adaxial}(1)\end{array}$} & Mean value & 38.0 & 28.1 & 1.2 & 6.2 & 5.9 & 13.6 & 6.5 & 0.6 \\
\hline & Std. Dev. & 13.4 & 5.6 & 0.3 & 2.0 & 2.1 & 5.2 & 1.6 & 0.2 \\
\hline & Max. & 62.5 & 37.2 & 1.6 & 9.0 & 10.7 & 24.2 & 9.3 & 1.2 \\
\hline & Min. & 15.5 & 20.0 & 0.9 & 3.0 & 2.7 & 6.1 & 4.0 & 0.3 \\
\hline \multirow{4}{*}{$\begin{array}{l}\text { RLA } 450^{\circ} \mathrm{C} \\
\text { abaxial (2) }\end{array}$} & Mean value & 43.4 & 27.0 & 0.8 & 5.7 & 4.5 & 12.2 & 5.9 & 0.4 \\
\hline & Std. Dev. & 14.4 & 5.5 & 0.3 & 1.7 & 1.4 & 4.5 & 1.7 & 0.1 \\
\hline & Max. & 62.4 & 38.6 & 1.5 & 8.2 & 7.2 & 22.7 & 8.7 & 0.7 \\
\hline & Min. & 14.6 & 19.5 & 0.5 & 3.0 & 2.8 & 6.8 & 3.2 & 0.3 \\
\hline \multirow{4}{*}{$\begin{array}{l}\text { RLA } 450^{\circ} \mathrm{C} \\
\text { total (3) }\end{array}$} & Mean value & 40.7 & 27.5 & 1.0 & 6.0 & 5.2 & 12.9 & 6.2 & 0.5 \\
\hline & Std. Dev. & 14.0 & 5.5 & 0.3 & 1.8 & 1.9 & 4.8 & 1.6 & 0.2 \\
\hline & Max. & 62.5 & 38.6 & 1.6 & 9.0 & 10.7 & 24.2 & 9.3 & 1.2 \\
\hline & Min. & 14.6 & 19.5 & 0.5 & 3.0 & 2.7 & 6.1 & 3.2 & 0.3 \\
\hline \multirow{4}{*}{$\begin{array}{l}\text { RLA } 550^{\circ} \mathrm{C} \\
\text { total }(4)\end{array}$} & Mean value & 39.3 & 24.6 & 0.6 & 8.9 & 7.1 & 14.3 & 4.8 & 0.4 \\
\hline & Std. Dev. & 9.7 & 2.0 & 0.1 & 2.7 & 2.8 & 4.1 & 1.5 & 0.1 \\
\hline & Max. & 50.7 & 27.0 & 0.7 & 12.4 & 11.4 & 20.1 & 6.5 & 0.6 \\
\hline & Min. & 26.6 & 22.1 & 0.4 & 5.0 & 3.9 & 9.6 & 3.1 & 0.3 \\
\hline
\end{tabular}

Std. Dev. = standard deviation; Max. = maximum recorded value; Min. = minimum recorded value.

(1) Calculated from analyses on 15 different areas.

(2) Calculated from analyses on 15 different areas.

(3) Combined results from (1) and (2).

(4) Calculated from analyses on 8 different areas.

ashes from herbaceous and agricultural grass, straw and residues are located in K-type and K-MA-type zones. This is the case of RLA, which is located in K-MA zone: $\sigma=51.2 \%, \tau=11.1 \%, \kappa=47.7 \%$. Very close but in K-type zone, is located SLA (from Roselló et al., 2015: $\sigma=30.3 \%, \tau=24.4 \%, \kappa=45.4 \%$ ).
In Fig. 5 the spodogram of the adaxial surface for RLA obtained at $550^{\circ} \mathrm{C}$ is observed. Some line-arranged dumbbell phytoliths were identified (Fig. 5a) surrounded by a smooth inorganic matrix. Interestingly, when the images are magnified (Fig. 5b-d), one can see that the phytholiths have rounded edges (compare to Fig. $3 \mathrm{~d}$ ) and 


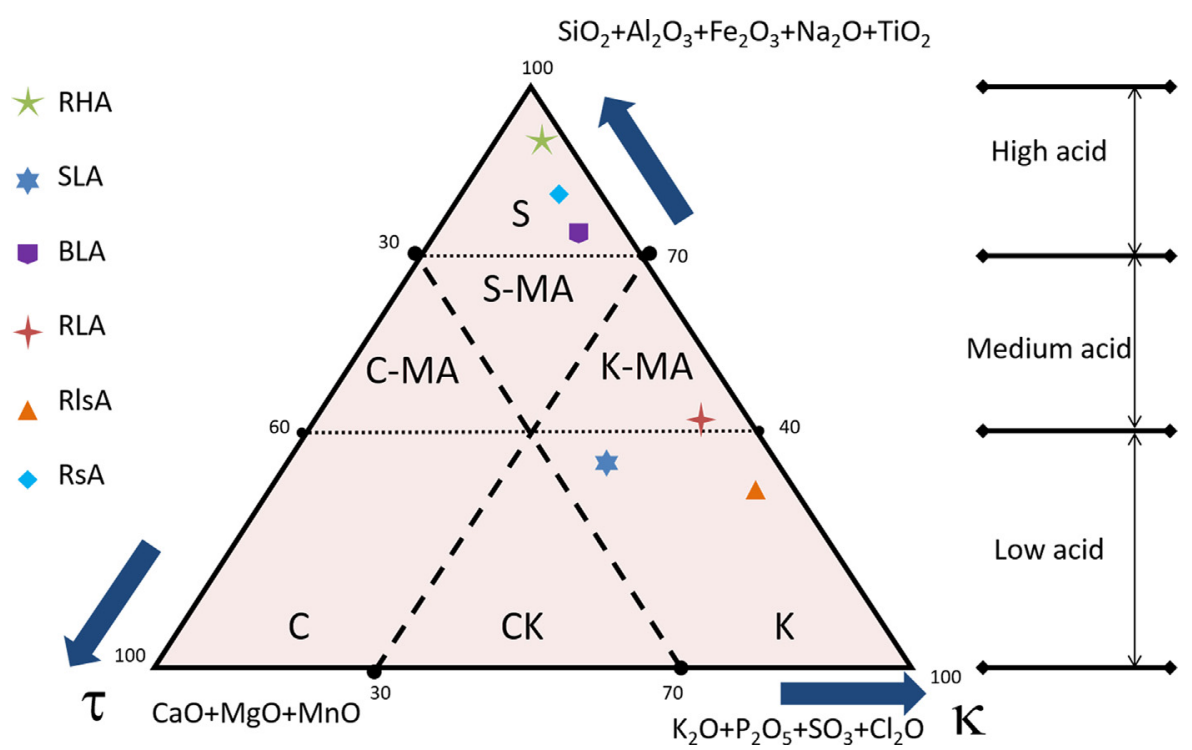

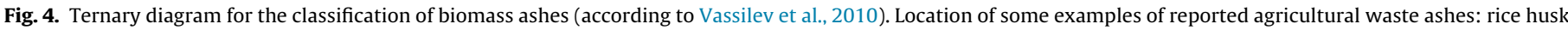

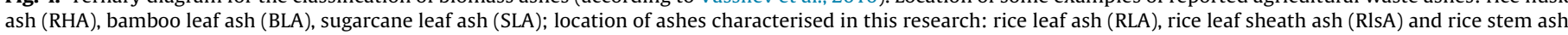
(RsA).
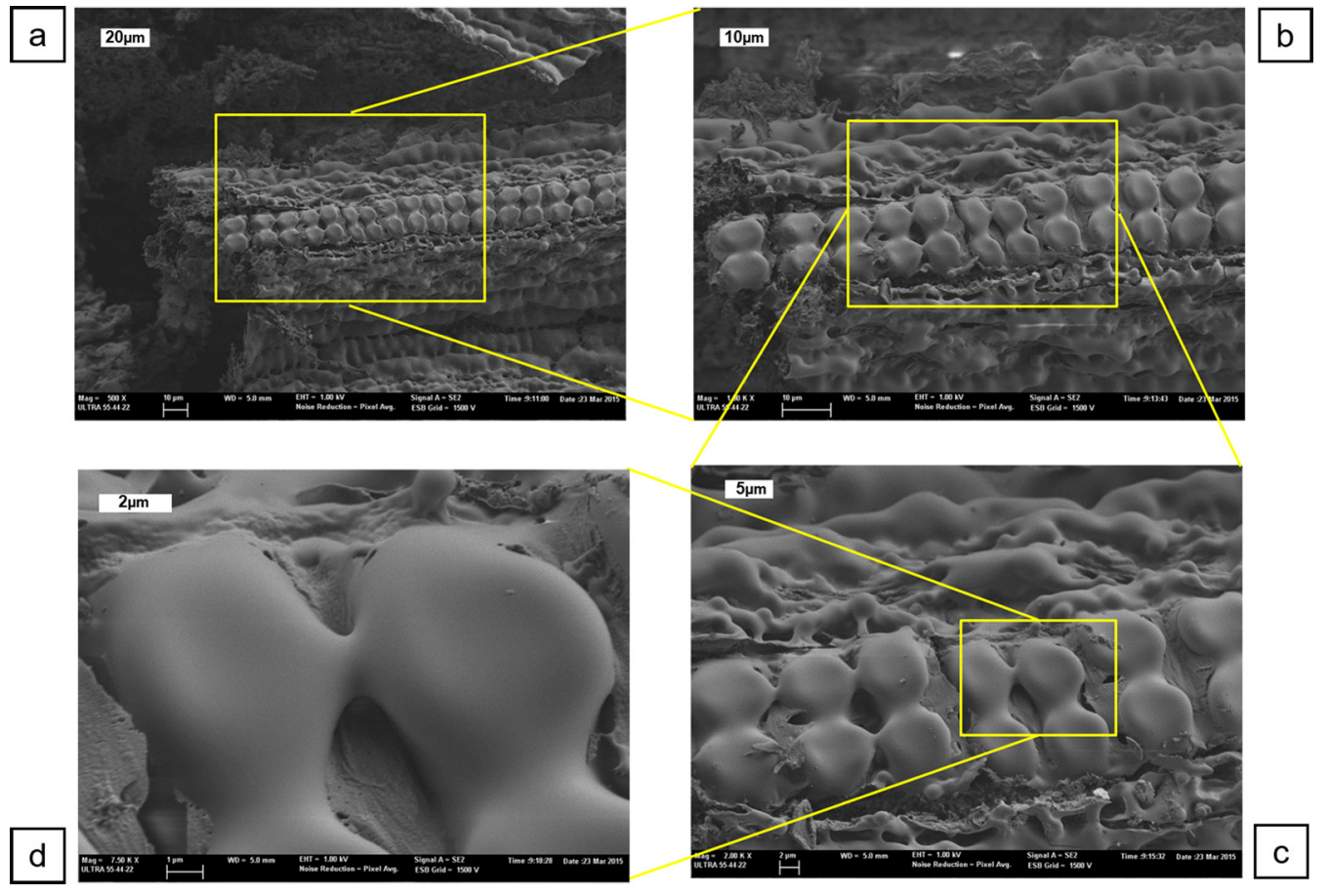

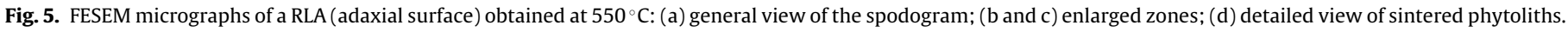

some of them are connected along certain sides. Apparently, this deformation is related to a semi-fusion or sinterisation process carried out during the calcination.

The same behaviour was observed for the abaxial surface (Fig. 6). In Fig. $6 a$ and $b$, a double chain of phytoliths corresponding to the longitudinal centre of the leaf (midrib, the central vein of the leaf) is shown. Fig. 6c shows highly altered phytoliths, probably due to a focalised high temperature during calcination. In Fig. 6d, a picture of the inorganic matrix after organic matter removal is shown: in this case, more rounded structures are observed compared to the matrix depicted in Fig. 3d.

The melting point of ashes depends on the percentage of inorganic elements (Biedermann and Obernberger, 2015). Thus, high percentages of alkalis ( $\mathrm{Na}, \mathrm{K}$ ) and chlorides result in a decrease in melting temperatures; on the contrary, presence of alkaline earth elements $(\mathrm{Ca}, \mathrm{Mg})$ increasing it. In general, straw ashes with low Ca content and high $\mathrm{K}$ and Si contents start to sinter and melt at lower temperatures than wood ashes (which are richer in $\mathrm{Ca}$ ) (Biedermann and Obernberger, 2015). Potassium is the key element that participates in the formation of troublesome species (e.g., formation of potassium salts, such as $\mathrm{KCl}$ and $\mathrm{K}_{2} \mathrm{SO}_{4}$ ). The $\mathrm{K}_{2} \mathrm{O}$ $\mathrm{SiO}_{2}$ binary system starts to melt in the range of $600-700{ }^{\circ} \mathrm{C}$ (Wang et al., 2012). Despite the temperature furnace being $550^{\circ} \mathrm{C}$, temperatures on the surface of the materials were probably higher as the combustion of organic matter released a significant quantity of heat. In these conditions, the temperature close to the sample was 

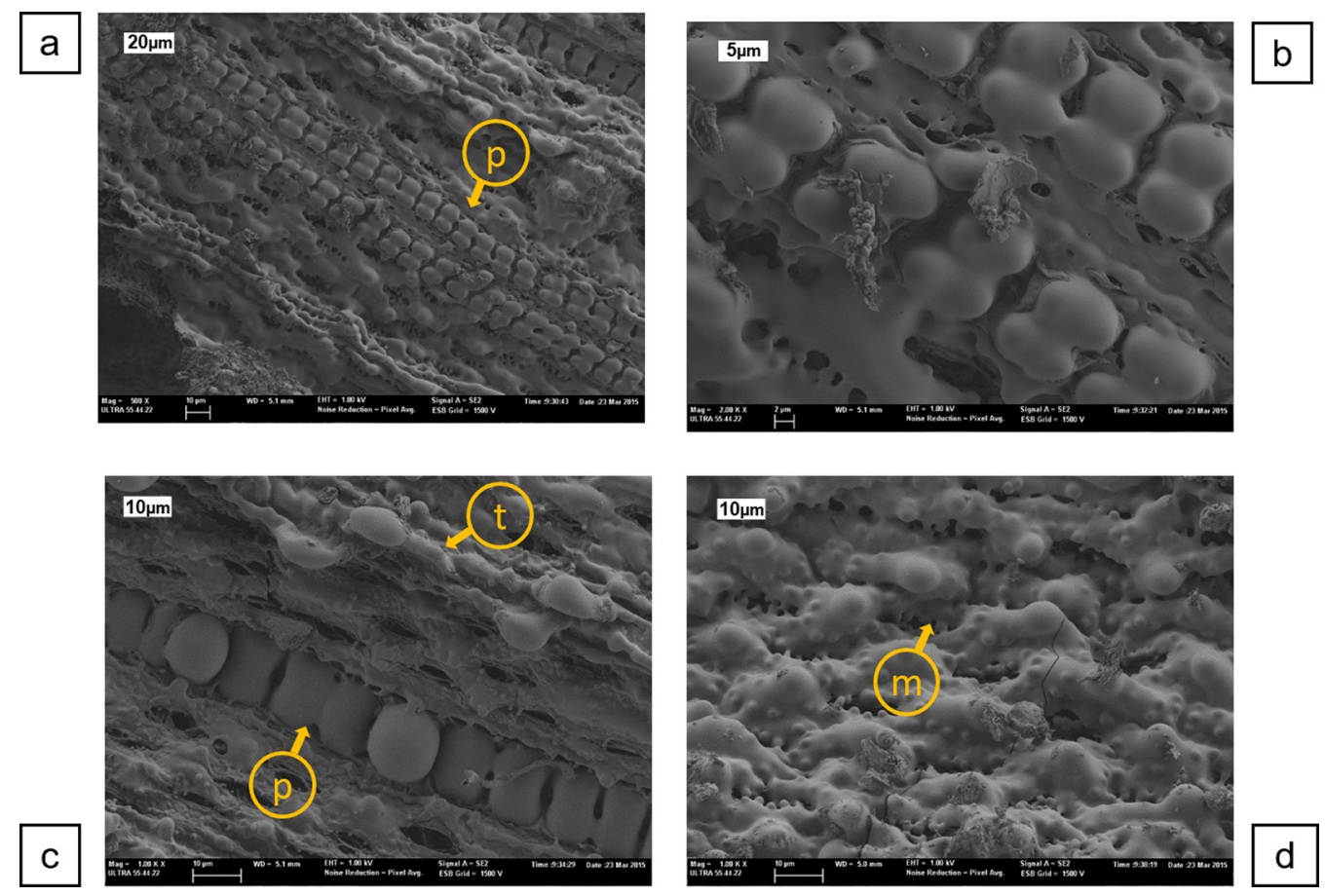

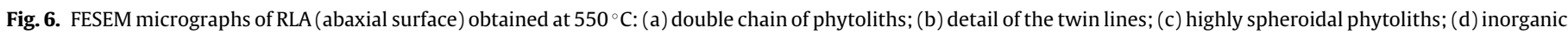
matrix.

certainly higher than $600^{\circ} \mathrm{C}$. This is the reason why all remaining structures after burning at $550^{\circ} \mathrm{C}$ appeared rounded. Furthermore, the matrix surrounding the phytoliths was affected: in this case, the presence of $\mathrm{Ca}$ and $\mathrm{Mg}$ did not prevent the sintering/melting process, as can be seen in Fig. $6 \mathrm{~d}$ for the matrix in the abaxial surface of rice leaf burned at $550^{\circ} \mathrm{C}$. This behaviour supports the relationship between initial deformation temperature (IDT) and the $\mathrm{K}_{2} \mathrm{O}$ content observed for biomass ashes, whereby IDT lowered when $\mathrm{K}_{2} \mathrm{O}$ increased (Niu et al., 2010).

The chemical composition of RLA calcined at $550{ }^{\circ} \mathrm{C}$ was also determined by EDS (eight individual analyses were carried out). Mean values are given in Table 2 . In this case, statistical analysis shown that there are differences $(P<0.05)$ in $\mathrm{Cl}, \mathrm{CaO}, \mathrm{MgO}$ and $\mathrm{SO}_{3}$ contents when compared with sample prepared at $450^{\circ} \mathrm{C}$.

RLA samples also were obtained by calcining the straw at 600 and $650^{\circ} \mathrm{C}$. Fig. 7 shows selected FESEM micrographs. Phytoliths in Fig. 7a-c showed that spodograms of ashes calcined at $600{ }^{\circ} \mathrm{C}$ appeared slightly sintered. In samples obtained at $650^{\circ} \mathrm{C}$, the sinterisation effect is highlighted: many phytoliths changed from their original shape to rounded dumbbell shape (Fig. 7d), spheroidal structures (Fig. 7e) or to produce a continuous line through the merging of phytoliths (Fig. 7f).

EDS analyses were performed on samples obtained at $650^{\circ} \mathrm{C}$. The calculated chemical compositions did not vary significantly with respect to those obtained at lower temperatures, except for chloride content. These analyses yield chloride contents in the range $0.15-0.04 \%$. This means that there was a removal of chlorides during treatment at this temperature. Probably, the chlorine was removed in the form of potassium chloride by volatilisation due to the low melting point of this salt $\left(776^{\circ} \mathrm{C}\right)$.

\subsection{Microscopic studies on rice leaf sheath and rice stem ashes}

Samples of leaf sheath (ls) and stem (s) were calcined at $450^{\circ} \mathrm{C}$. FESEM micrographs of the obtained ashes (RlsA and RsA, respectively) are showed in Fig. 8. External parts (Fig. 8a and c) showed phytoliths and similar texture to that of leaf blades described above.
However, internal structures (Fig. 8b and d) were different and a very porous skeleton was identified. Chemical analysis (EDS) of the ashes was conducted in order to compare the percentages of the main oxides. Values are summarised in Table 3. Statistical analysis showed that the chemical compositions for RLA and RlsA are different $(P<0.05)$ for all oxides, except for $\mathrm{SiO}_{2}$. The $\mathrm{SiO}_{2}$ content was higher for the external part of the leaf sheath (37.7\%) than for the internal part (23.3\%), although the difference is not statistically significant. Significant differences $(P<0.05)$ were only found for $\mathrm{K}_{2} \mathrm{O}, \mathrm{SO}_{3}$ and $\mathrm{Na}_{2} \mathrm{O}$. Interestingly, $\mathrm{K}_{2} \mathrm{O}$ and chloride contents were higher for RlsA than RLA: chloride content was more than five times greater in RlsA. In the Vassilev's ternary diagram (see Fig. 4), RlsA belongs to K-zone ( $\sigma=32.6 \%, \tau=4.2 \%, \kappa=63.2 \%)$.

On the contrary RsA showed a high percentage of $\mathrm{SiO}_{2}$ (mean value $84.3 \%$ ). Obviously, the rest of components were low, especially chloride, which scarcely reached $0.1 \%$. From a statistical point of view, there is a significant difference $(P<0.05)$ between all oxides, except $\mathrm{CaO}$ and $\mathrm{Na}_{2} \mathrm{O}$, with respect to the RLA. Thus, the position of RLA in the Vassilev's diagram (see Fig. 4a) is in the S-zone: $\sigma=84.7 \%, \tau=8.7 \%, \kappa=6.6 \%$.

\subsection{Reactivity studies on rice straw ashes}

In general terms, rice straw collected from the field is composed of leafs, stems and leaf sheaths; additionally, is very common that some soil particles (sand, clays, feldspar) appear together the biomass. In this study, a sample of rice straw was collected and calcined in order to analyse the pozzolanic properties of the ash. Three calcining temperatures $\left(450^{\circ} \mathrm{C}, 550^{\circ} \mathrm{C}\right.$ and $\left.650^{\circ} \mathrm{C}\right)$ were selected for producing the corresponding ashes (RSA-450, RSA-550, RSA650).

These samples were characterised by means of thermogravimetry (TG), FTIR and powder XRD.

The thermogravimetric analysis curve (Fig. 9) for RSA-450 showed that decomposition of the organic matter/carbon was not completed at $450^{\circ} \mathrm{C}$, although there was a mass loss (6.92\%) in the $350-650^{\circ} \mathrm{C}$ range. Also a mass loss was beginning at $900^{\circ} \mathrm{C}$, which 


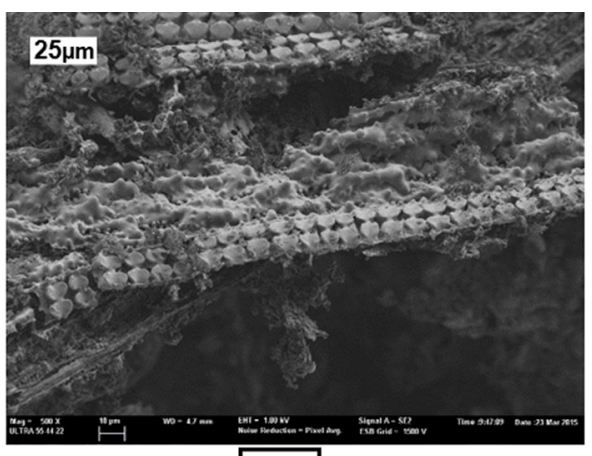

a
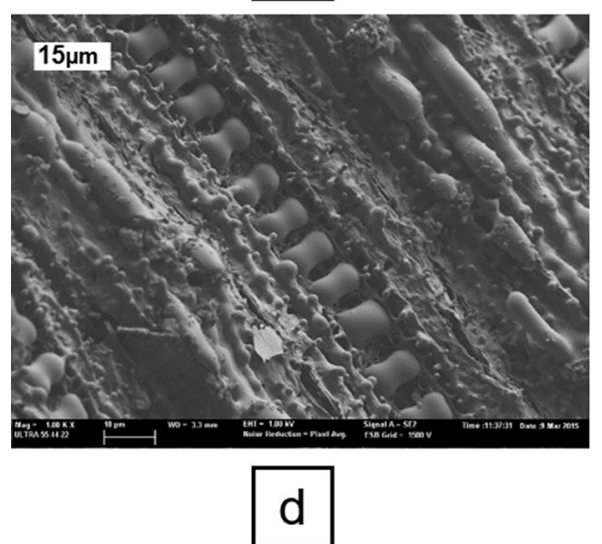

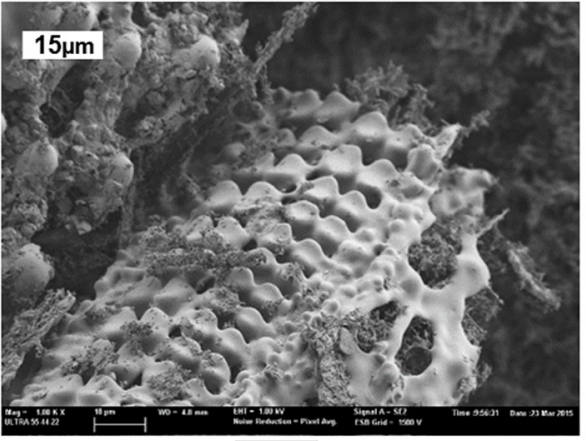

b
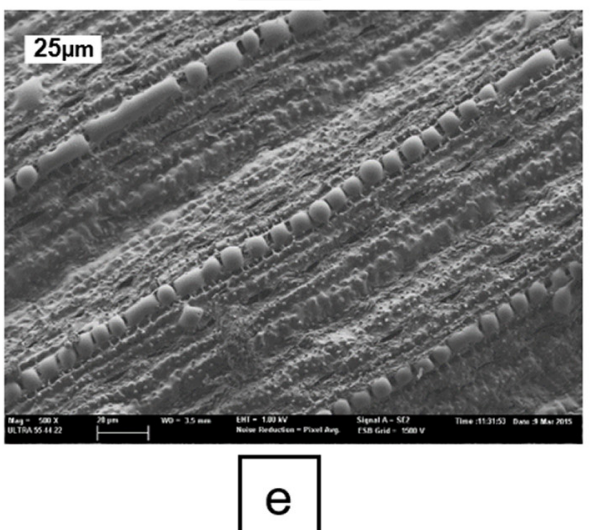

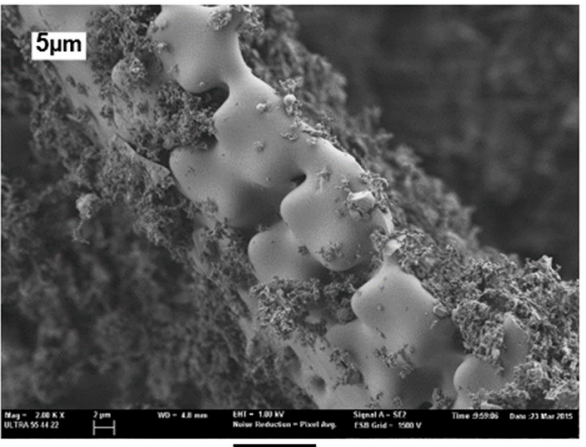

c
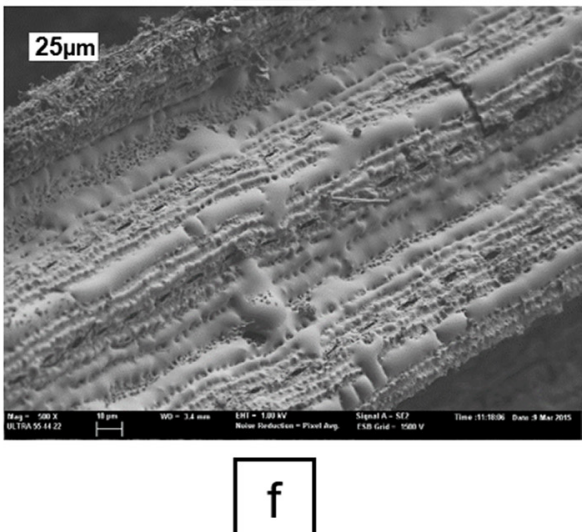

Fig. 7. FESEM micrographs for RLA obtained at $600^{\circ} \mathrm{C}$ (a, b, c: slightly sintered phytoliths) and at $650^{\circ} \mathrm{C}(\mathrm{d}$, e, f: highly sintered phytoliths).
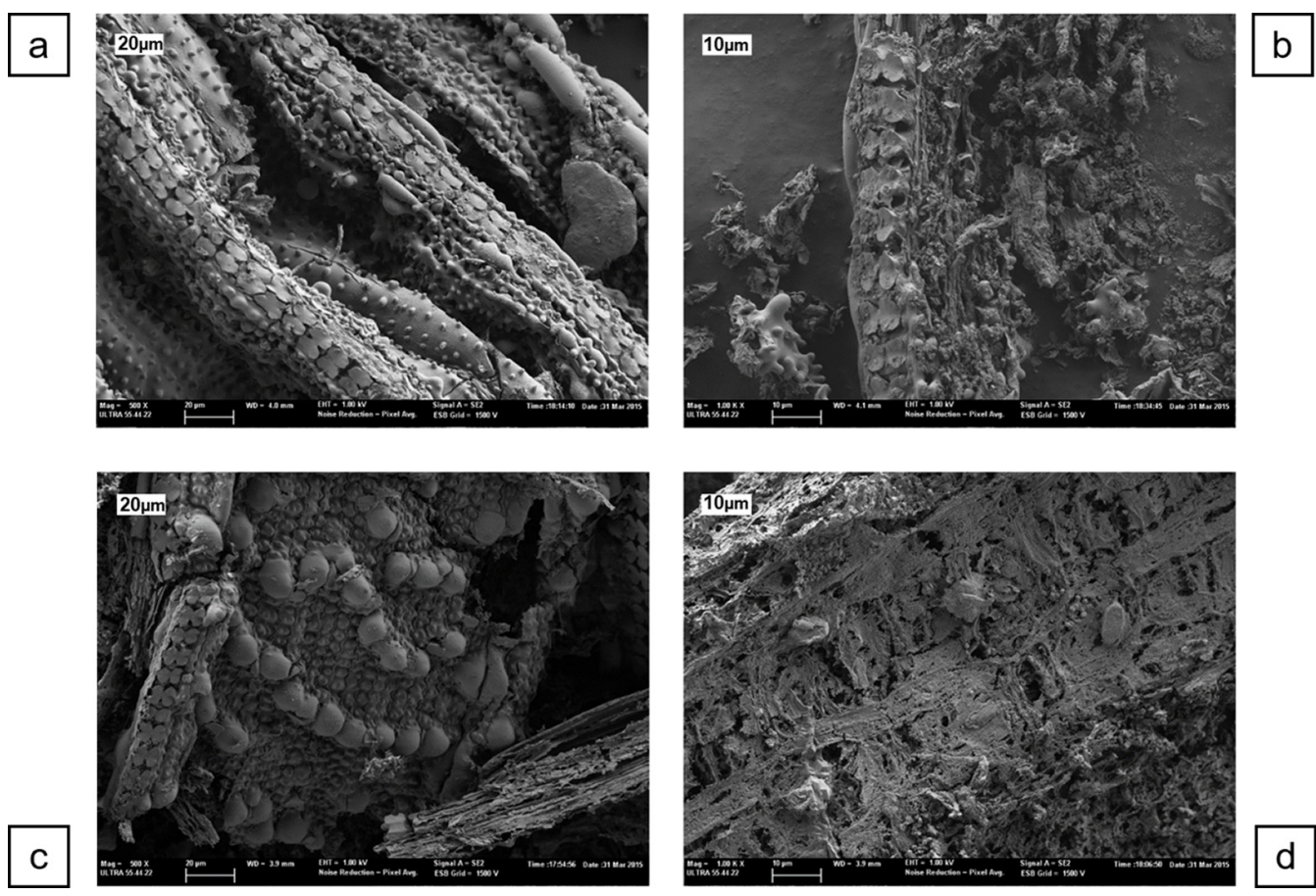

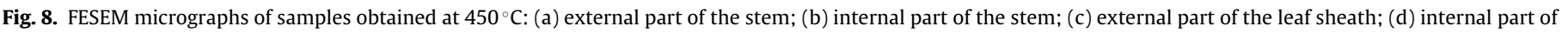
the leaf sheath.

is related to the fusion/evaporation of potassium sulphate (pure $\mathrm{K}_{2} \mathrm{SO}_{4}$ melts at $1069^{\circ} \mathrm{C}$ ). Conversely, the sample obtained at $550^{\circ} \mathrm{C}$ did not show (Fig. 9) any significant mass loss related to organic matter/carbon, which means that this temperature is enough for removing organic compounds in rice straw; RSA-550 ${ }^{\circ} \mathrm{C}$ also shows a similar initiation of mass loss at $900^{\circ} \mathrm{C}$.

FTIR spectra for these ashes are depicted in Fig. 10. The main absorption bands are related to $\mathrm{Si}-\mathrm{O}$ vibrations, in accordance 
Table 3

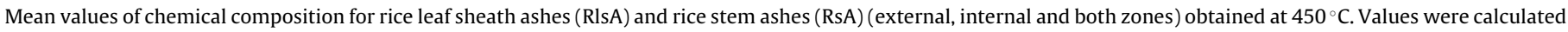
from EDS analysis on a $115 \mu \mathrm{m} \times 85 \mu \mathrm{m}$ area.

\begin{tabular}{|c|c|c|c|c|c|c|c|c|c|}
\hline Sample & Parameter & $\mathrm{SiO}_{2}$ & $\mathrm{~K}_{2} \mathrm{O}$ & $\mathrm{Cl}$ & $\mathrm{CaO}$ & $\mathrm{MgO}$ & $\mathrm{P}_{2} \mathrm{O}_{5}$ & $\mathrm{SO}_{3}$ & $\mathrm{Na}_{2} \mathrm{O}$ \\
\hline \multirow{4}{*}{$\begin{array}{l}\text { RlsA } 450^{\circ} \mathrm{C} \\
\text { external (1) }\end{array}$} & Mean value & 37.7 & 33.4 & 4.7 & 1.5 & 2.7 & 16.2 & 3.2 & 0.7 \\
\hline & Std. Dev. & 17.8 & 5.8 & 2.0 & 1.6 & 1.6 & 7.2 & 1.1 & 0.4 \\
\hline & Max. & 63.5 & 41.2 & 8.7 & 3.8 & 5.7 & 28.1 & 5.1 & 1.4 \\
\hline & Min. & 9.8 & 24.5 & 1.3 & 0.00 & 0.5 & 7.4 & 1.3 & 0.2 \\
\hline \multirow{4}{*}{$\begin{array}{l}\text { RlsA } 450^{\circ} \mathrm{C} \\
\text { internal (2) }\end{array}$} & Mean value & 23.3 & 40.6 & 6.9 & 1.0 & 3.4 & 18.1 & 4.9 & 1.3 \\
\hline & Std. Dev. & 19.7 & 8.0 & 5.0 & 1.3 & 1.0 & 5.9 & 1.3 & 0.4 \\
\hline & Max. & 59.8 & 49.4 & 16.5 & 3.0 & 4.6 & 25.8 & 7.0 & 2.0 \\
\hline & Min. & 0.00 & 27.9 & 1.3 & 0.00 & 1.1 & 7.2 & 2.2 & 0.5 \\
\hline \multirow{4}{*}{$\begin{array}{l}\text { RlsA } 450^{\circ} \mathrm{C} \\
\text { total (3) }\end{array}$} & Mean value & 32.0 & 36.3 & 5.6 & 1.3 & 3.0 & 17.2 & 3.9 & 0.9 \\
\hline & Std. Dev. & 19.56 & 7.51 & 3.60 & 1.48 & 1.44 & 6.70 & 1.45 & 0.48 \\
\hline & Max. & 63.5 & 49.4 & 16.5 & 3.8 & 5.7 & 28.1 & 7.0 & 2.0 \\
\hline & Min. & 0.00 & 24.5 & 1.3 & 0.00 & 0.5 & 7.2 & 1.3 & 0.2 \\
\hline \multirow{4}{*}{$\begin{array}{l}\text { RsA } 450{ }^{\circ} \mathrm{C} \\
\text { external (4) }\end{array}$} & Mean value & 83.0 & 4.7 & 0.2 & 4.8 & 4.2 & 1.1 & 1.5 & 0.5 \\
\hline & Std. Dev. & 7.2 & 2.1 & 0.2 & 2.4 & 2.8 & 0.8 & 0.8 & 0.2 \\
\hline & Max. & 95.0 & 9.0 & 0.6 & 9.6 & 11.9 & 3.1 & 3.6 & 1.1 \\
\hline & Min. & 67.3 & 2.1 & 0.00 & 0.8 & 1.3 & 0.00 & 0.6 & 0.2 \\
\hline \multirow{4}{*}{$\begin{array}{l}\text { RsA } 450{ }^{\circ} \mathrm{C} \\
\text { internal (5) }\end{array}$} & Mean value & 86.1 & 3.0 & 0.00 & 6.3 & 2.0 & 1.1 & 1.2 & 0.4 \\
\hline & Std. Dev. & 2.4 & 0.5 & 0.00 & 1.1 & 0.7 & 0.3 & 0.4 & 0.1 \\
\hline & Max. & 90.8 & 3.8 & 0.00 & 8.1 & 3.1 & 1.6 & 1.7 & 0.6 \\
\hline & Min. & 83.3 & 2.3 & 0.00 & 4.1 & 1.2 & 0.8 & 0.6 & 0.2 \\
\hline \multirow{4}{*}{$\begin{array}{l}\mathrm{RsA} 450^{\circ} \mathrm{C} \\
\text { total (6) }\end{array}$} & Mean value & 84.3 & 4.0 & 0.1 & 5.4 & 3.4 & 1.1 & 1.4 & 0.5 \\
\hline & Std. Dev. & 5.9 & 1.9 & 0.2 & 2.1 & 2.4 & 0.6 & 0.7 & 0.2 \\
\hline & Max. & 95.0 & 9.0 & 0.6 & 9.6 & 11.9 & 3.1 & 3.6 & 1.1 \\
\hline & Min. & 67.3 & 2.1 & 0.0 & 0.8 & 1.2 & 0.0 & 0.6 & 0.2 \\
\hline
\end{tabular}

Std. Dev = standard deviation; Max = maximum value recorded; Min = minimum value recorded

(1) Calculated from analyses on 15 different areas.

(2) Calculated from analyses on 15 different areas.

(3) Combined results from (1) and (2).

(4) Calculated from analyses on 15 different areas.

(5) Calculated from analyses on 15 different areas.

(6) Combined results from (4) and (5).

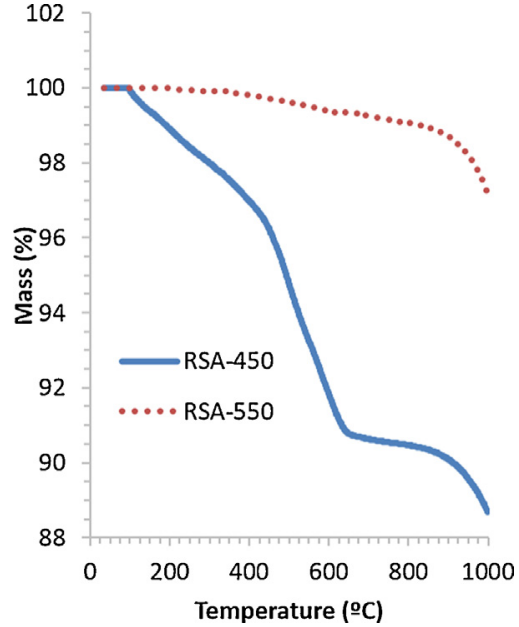

Fig. 9. Thermogravimetric curves for RSA-450 and RSA-550 (dried air atmosphere, $20^{\circ} \mathrm{C} \mathrm{min}^{-1}$ heating rate).

with the siliceous nature of the ashes. The most intense bands are 1056-1035, 795-785, 617 and $453 \mathrm{~cm}^{-1}$. Also, absorption bands related to the presence of carbonate anions (probably due to the presence of calcium carbonate) are observed: 1411-1406 and $877 \mathrm{~cm}^{-1}$. These $\mathrm{C}-\mathrm{O}$ bands disappeared for RSA-650, suggesting that the small amount of carbonate present in the ash is decomposed (decarbonation) at $650^{\circ} \mathrm{C}$.

Finally, in order to complete the characterisation of the ashes, XRD patterns were collected (Fig. 11). Significant major peaks (28.4 ${ }^{\circ}$ and $40.6^{\circ}$ ) are related to the presence of sylvite $(\mathrm{KCl}$, PDFcard 411476). This crystalline compound is easily identified because

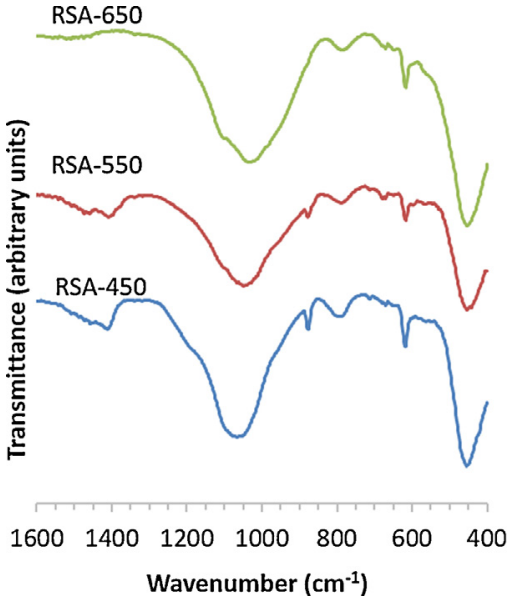

Fig. 10. FTIR spectra ( $400-1600 \mathrm{~cm}^{-1}$ range) for RSA-450, RSA-550 and RSA-650.

solid phases in ashes are mainly amorphous in nature. The baseline deviation in the range $2 \theta=15-30^{\circ}$ is representative of amorphous silica. Some traces of quartz $\left(\mathrm{SiO}_{2}\right.$, PDFcard 331161) are probably due to soil contamination of the rice straw. Interestingly, there was no evidence of the formation of cristobalite or trydimite. This means that conversion of the straw into ashes at a temperature in the $450-650^{\circ} \mathrm{C}$ range, does not achieve the crystallisation of amorphous silica. This behaviour has an important consequence because the pozzolanic reactivity of ashes depends on the silica phases: crystalline phases do not react easily towards calcium hydroxide $(\mathrm{CH})$, whereas amorphous silica reacts at room temperature in wet conditions. Secondary minerals are also present in 


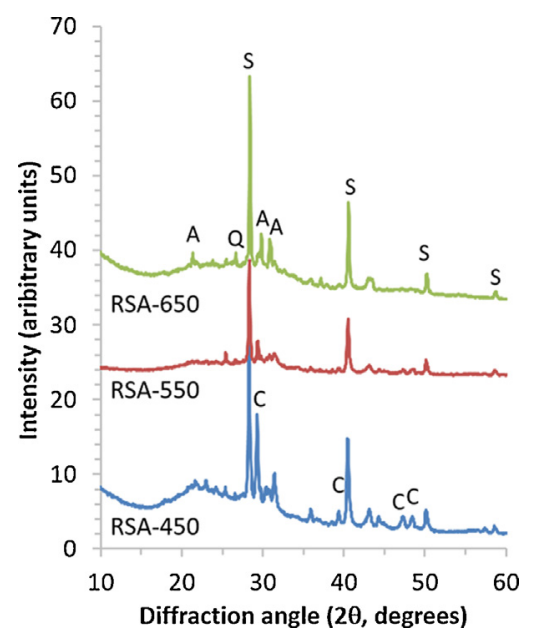

Fig. 11. $X R D$ patterns for RSA-450, RSA-550 and RSA-650. Key: $S=$ sylvite; $C=$ calcite; $\mathrm{Q}=$ quartz; $\mathrm{A}=$ arcanite.

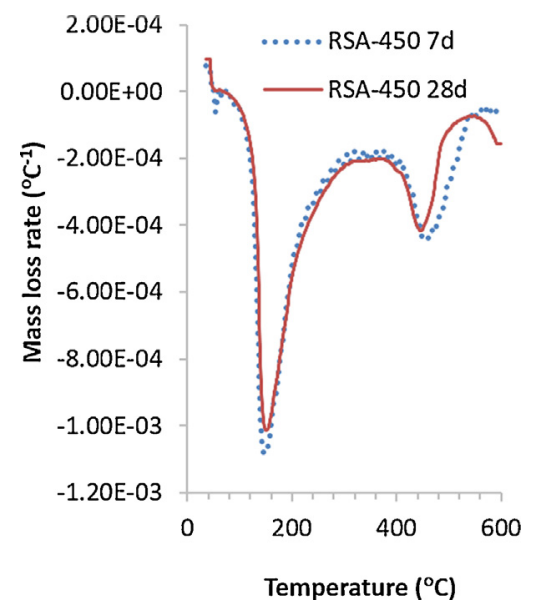

Fig. 12. DTG curves of RSA-450: $\mathrm{CH}$ (1:1) pastes cured for 7 and 28 days.

the ashes: arcanite $\left(\mathrm{K}_{2} \mathrm{SO}_{4}\right.$, PDFcard 050613) and calcite $\left(\mathrm{CaCO}_{3}\right.$, PDFcard 050586). The peaks corresponding to calcite have less intensity in the RSA-650 sample, confirming the decomposition of the carbonated mineral at this temperature, as suggested from FTIR results.

In order to quantify the reactivity of RSA samples, selected mixtures with calcium hydroxide $\left(\mathrm{Ca}(\mathrm{OH})_{2}, \mathrm{CH}\right)$ were prepared and hydrated. Pastes with RSA-450 and RSA-550, prepared with a RSA:CH (1:1) mass ratio were characterised by thermogravimetry (after 7 and 28 days hydration). Derivative thermogravimetric curves (DTG) of RSA-450 pastes are depicted in Fig. 12. In both DTG curves ( 7 and 28 days), a peak centred at about $150^{\circ} \mathrm{C}$ was present, related to the dehydration process of calcium silicate hydrate $(\mathrm{C}-\mathrm{S}-\mathrm{H})$. This compound is typically produced as consequence of the pozzolanic reaction between amorphous silica and $\mathrm{CH}$. Also, a peak appeared at $450^{\circ} \mathrm{C}$ related to the decomposition of the small amount of remaining $\left(\mathrm{Ca}(\mathrm{OH})_{2}\right)$. The total mass loss for the temperature range of $35-600^{\circ} \mathrm{C}$ was very high: $16.09 \%$ for 7 days and $15.47 \%$ for 28 days; conversely, the mass loss attributed to $\mathrm{CH}$ was very low ( 2.15 and $1.63 \%$, respectively). These data revealed that the pozzolanic reaction was fast and that most of the reaction products were produced in the first 7 days of hydration. This behaviour implies the amorphous nature of the silica present in the ash. The total amount of $\mathrm{CH}$ fixed by the RSA-450 ash was very high: $82 \%$ for 7 days and $87 \%$ for 28 days. Similar results were found

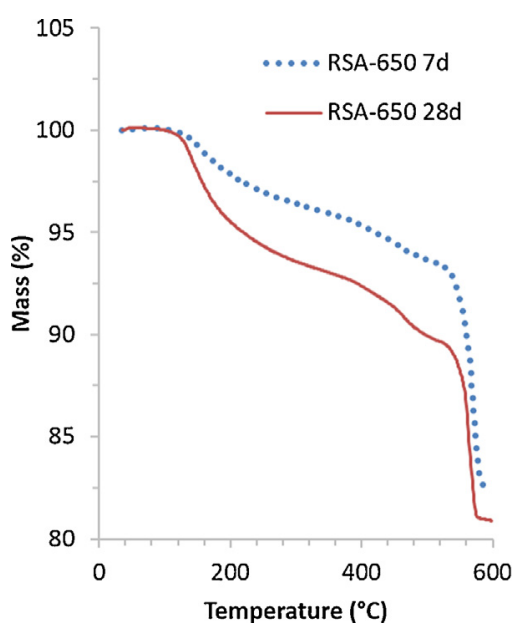

Fig. 13. TG curves of RSA-650: $\mathrm{CH}$ (3:7) pastes cured for 7 and 28 days.

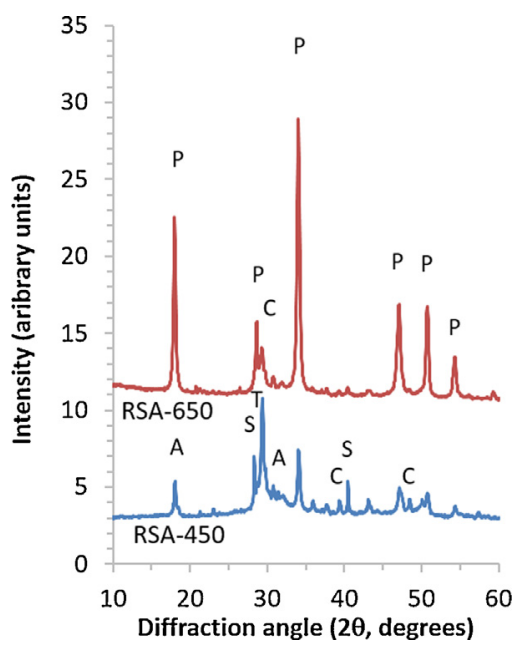

Fig. 14. XRD patterns for RSA-450: $\mathrm{CH}(1: 1)$ paste and RSA-650: $\mathrm{CH}(3: 7)$ paste, both cured at room temperature for 28 days. Key: $\mathrm{S}=$ sylvite; $\mathrm{C}=$ calcite; $\mathrm{A}=$ arcanite; $\mathrm{P}=$ portlandite; $\mathrm{T}=$ tobermorite.

for RSA-550, suggesting that both calcining temperatures yielded excellent reactive ashes.

RSA-650 reactivity was also assessed by means of the reactivity towards calcium hydroxide in a $\mathrm{RSA}: \mathrm{CH}$ (3:7) ratio. In this case, with respect to the above-mentioned pastes, the relative amount of $\mathrm{CH}$ is much higher (70\%). In these conditions, this reagent was in high excess and will be not totally consumed, as can be seen in the TG curves for 7 and 28 days of curing depicted Fig. 13. In these curves, a mass loss in the range $540-580^{\circ} \mathrm{C}$ corresponding to the decomposition of $\mathrm{Ca}(\mathrm{OH})_{2}$ was observed. From the corresponding calculated mass losses for both curing ages, it can be stated that $40 \%$ and $54 \%$, respectively, of the $\mathrm{Ca}(\mathrm{OH})_{2}$ was chemically combined in the reaction. In the TG curve, mass loss related to the dehydration of $\mathrm{C}-\mathrm{S}-\mathrm{H}$ gel (range $120-200^{\circ} \mathrm{C}$ ) is also observed, similar to that found in $1: 1$ pastes.

These pastes also were characterised by means XRD. In Fig. 14, XRD patterns for 1:1 RSA-450: $\mathrm{CH}$ paste and 3:7 RSA-650: $\mathrm{CH}$ paste, both cured at room temperature for 28 days, are shown. Firstly, for the paste with the lowest $\mathrm{CH}$ proportion (1:1 paste), it may be noticed that the baseline deviation, which occurred in the ash (see Fig. 11), practically disappeared and the baseline deviation moved to a higher diffraction angle range $\left(2 \theta=27-33^{\circ}\right)$. This was due to the transformation of the amorphous silica to $\mathrm{C}-\mathrm{S}-\mathrm{H}$ gel as a consequence of the pozzolanic reaction. The most intense and broad 


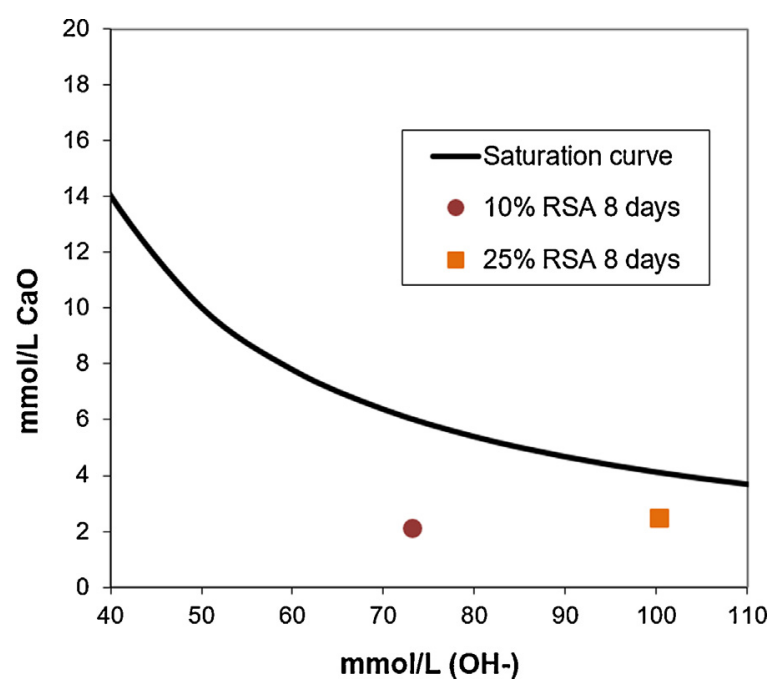

Fig. 15. Frattini test results after 8 days curing at $40^{\circ} \mathrm{C}$ for blended cements with RSA ( $10 \%$ and $25 \%$ replacement percentages).

\section{Table 4}

Compressive strengths (in MPa, standard deviation in parentheses) for mortars after 7 days and 28 days of curing.

\begin{tabular}{lll}
\hline Mortar & 7 days & 28 days \\
\hline OPC control & $54.9(0.7)$ & $62.7(0.6)$ \\
$10 \%$ RSA & $54.1(1.8)$ & $67.1(2.0)$ \\
$25 \%$ RSA & $45.8(1.3)$ & $58.9(1.8)$ \\
\hline
\end{tabular}

peak was found at $2 \theta=29.9^{\circ}$, which corresponds to the tobermoritic phase $\left(\mathrm{Ca}_{5} \mathrm{Si}_{6} \mathrm{O}_{16}(\mathrm{OH})_{2} \cdot 4\left(\mathrm{H}_{2} \mathrm{O}\right)\right)$ and this peak overlapped the main peak of calcite (which was present in the ash and also as an impurity in the calcium hydroxide used as reagent for the paste preparation). Furthermore, peaks belonging to sylvite and arcanite were easily identified. Additionally, main peaks from the portlandite $\left(\mathrm{Ca}(\mathrm{OH})_{2}\right.$, PDFcard 040733) also are shown: these peaks were of low intensity, demonstrating the low remaining quantity of portlandite in the paste after 28 days of curing. These results corroborate those from the thermogravimetric studies and confirm the high reactivity of the ash towards $\mathrm{CH}$ in the pozzolanic process. For the paste with the highest $\mathrm{CH}$ proportion (3:7 paste) and because important part of the calcium hydroxide remained unreacted after 28 days of curing (assessed by thermogravimetric analysis), the most intense peaks observed (Fig. 14) belonging to portlandite. Also, calcite was identified as the main crystalline component because of its presence in the $\mathrm{CH}$ reagent. Sylvite and arcanite were not observed due to the intensity of the portlandite peaks. For the same reason the tobermoritic phase was also difficult to observe.

Reactivity of RSA was also assessed by means compressive strength of mortars and pozzolanicity test (Frattini). Blended cements by mixing OPC and RSA were prepared: $10 \%$ and $25 \%$ replacement percentages of RSA were tested. Results from the Frattini test obtained after 8 days of reaction at $40^{\circ} \mathrm{C}$ are showed in Fig. 15. It can be noticed that the points corresponding to RSA containing blends are below the saturation curve. This behaviour confirms the pozzolanic reactivity of the ash.

Mortars cured after 7 and 28 days of curing were tested in compression (six values for each cement and for each curing time). Compressive strengths are summarised in Table 4. Mortar with $10 \%$ RSA reached $98.4 \%$ of the strength found for OPC control after 7 days, and $107.1 \%$ after 28 days; and mortar with $25 \%$ RSA reached $83.3 \%$ at 7 days and $98.4 \%$ after 28 days. All these results confirmed the high pozzolanic reactivity of RSA and the strong contribution of this type of reactivity on the strength development of mortars.

\section{Conclusions}

RSA is characterised from microscopic, chemical composition and reactivity point of views. Different parts of the rice straw have different chemical compositions when transformed to ashes: rice leaf ash (RLA), rice leaf sheath ash (RlsA) and rice stem ash (RsA).

Microscopic studies (optical and FESEM) revealed heterogeneity in the distribution of chemical elements in ashes according to the cellular structure remaining after organic matter removal (spodograms). The highest concentration of $\mathrm{SiO}_{2}$ was found for dumbbell shape phytoliths. In the global chemical composition of ashes, $\mathrm{SiO}_{2}$ was the main oxide present and $\mathrm{K}_{2} \mathrm{O}$ was the second main oxide for RLA and RlsA, whereas $\mathrm{CaO}$ was the second most abundant for RsA.

RLA presented a mean chemical composition with $40.7 \% \mathrm{SiO}_{2}$ and $27.5 \% \mathrm{~K}_{2} \mathrm{O}$. Also chloride content was relatively high (1.0\% by mass). According to Vassilev's classification, this ash belongs to the K-MA zone (medium acid). These ashes suffer significant sinterisation at $650^{\circ} \mathrm{C}$ due to the presence of potassium chloride. RlsA was classified accordingly to Vassilev's in the K-zone (low acid) because of its low $\mathrm{SiO}_{2}$ content and high $\mathrm{K}_{2} \mathrm{O}$ percentage. Noticeably, chloride content found for this ash was five-times greater than that found for RLA. RsA presented a very high $\mathrm{SiO}_{2}$ percentage (84.3\%) and it was classified in the S-zone (high acid).

RSA was tested from the reactivity point of view in order to assess the possibilities for its reuse in cementing systems. Results from pastes made by mixing RSA and calcium hydroxide showed that the pozzolanic reactivity of the ashes is important and cementing $\mathrm{C}-\mathrm{S}-\mathrm{H}$ gel is formed after 7 and 28 days at room temperature. This reactivity was due to the amorphous nature of the silica $\left(\mathrm{SiO}_{2}\right)$ in the ash. RSA:CH (1:1) pastes showed a fixation of $85 \%$ of available calcium hydroxide and (3:7) pastes a fixation of 54\%. OPC-RSA blended cements showed a good performance in terms of compressive strength development, and $107 \%$ and $98 \%$ of the strength for the control mortar was achieved after 28 of curing for $10 \%$ and $25 \%$ RSA replacement percentages.

These reactivity results are very promising for the reuse of ashes from this biomass (rice straw) in cementing systems, e.g., as pozzolanic supplementary materials in Portland cement or also as silica-based supplementary precursor for geopolymers (alkali activated materials).

\section{Acknowledgements}

The authors acknowledge the financial support of the Ministerio de Economía y Competitividad MINECO, Spain, and FEDER funding [Project: BIA2015-70107-R]. The authors thank the Electron Microscopy Service of the Universitat Politècnica de València (Spain).

\section{References}

Abdel-Rahman, M.A., Abdel-Shakour, E.H., Hassan, S.E., Refaat, B.M., Nour El-Din, M., Ewais, E.E., Alrefaey, H.M.A., 2015. Effects on environmental factors and compost additives on Bacillus sonorensis 7-1v, a cellulytic strain able to degrade rice straw under solid state fermentation. Int. J. Adv. Res. Biol. Sci. 2, 241-251.

Abou-Sekkina, M.M., Issa, R.M.A., Bastawisy, A.E.M., El-Helece, W.A., 2010.

Characterization and evaluation of thermodynamic parameters for Egyptian heap fired Rice Straw Ash (RSA). Int. J. Chem. 2, 81-88.

Anala, R., Nambisan, P., 2015. Study of morphology and chemical composition of phytoliths on the surface of paddy straw. Paddy Water Environ. 13, 521-527, http://dx.doi.org/10.1007/s10333-014-0468-5.

Angst, U., Elsener, B., Larsen, C.L., Vennesland, O., 2009. Critical chloride content in reinforced concrete - a review. Cem. Concr. Res. 39, 1122-1138, http://dx.doi. org/10.1016/j.cemconres.2009.08.006.

Aprianti, E., Shafigh, P., Bahri, S., Farahani, J.N., 2015. Supplementary cementitious materials origin from agricultural wastes - a review. Constr. Build. Mater. 74, 176-187, http://dx.doi.org/10.1016/j.conbuildmat.2014.10.010.

Ataie, F.F., Juenger, M.C.G., Taylor-Lange, S.C., Riding, K.A., 2015. Comparison of the retarding mechanisms of zinc oxide and sucrose on cement hydration and 
interactions with supplementary cementitious materials. Cem. Concr. Res. 72 128-136, http://dx.doi.org/10.1016/j.cemconres.2015.02.023.

Barceló, L., Kline, J., Walenta, G., Gartner, E., 2014. Cement and carbon emissions. Mater. Struct. 47 (6), 1055-1065, http://dx.doi.org/10.1617/s11527-013-0114-

Biedermann, F., Obernberger, F., 2015. Ash-Related Problems During Biomass Combustion and Possibilities for a Sustainable Ash Utilization. http://www. bios-bioenergy.at/uploads/media/Paper-Biedermann-AshRelated-2005-10-11. pdf (accessed 28.7.16)

Binici, H., Yucegok, F., Aksogan, O., Kaplan, H., 2008. Effect of corncob, wheat straw, and plane leaf ashes as mineral admixtures on concrete durability. J. Mater. Civ. Eng. 20, 478-483, http://dx.doi.org/10.1061/(ASCE)08991561(2008)20:7(478)

Binod, P., Sindhu, R., Singhania, R.R., Vikram, S., Devi, L., Nagalakshmi, S., Kurien, N., Sukumaran, R.K., Pandey, A., 2010. Bioethanol production from rice straw: an overview. Bioresour. Technol. 101, 4767-4774, http://dx.doi.org/10.1016/j. biortech.2009.10.079.

Bouzón, N., Payá, J., Borrachero, M.V., Soriano, L., Tashima, M.M., Monzó, J., 2014. Refluxed rice husk ash/NaOH suspension for preparing alkali activated binders. Mater. Lett. 115, 72-74, http://dx.doi.org/10.1016/j.matlet.2013.10.001.

CEMBUREAU, 2014. Activity Report, http://www.cembureau.eu/sites/default/files/ Activity\%20Report\%202014_website_1.pdf (accessed 28.7.16)

Cobreros, C., Reyes-Araiza, J.L., Nava, R., Rodríguez, M., Mondragón-Figueroa, M., Apatiga, L.M., Rivera-Muñoz, E.M., 2015. Barley straw ash: pozzolanic activity and comparison with other natural and artificial pozzolans from Mexico. Bioresources 10, 3757-3774, http://dx.doi.org/10.15376/biores.10.2.37573774.

Cordeiro, G.C., Sales, C.P., 2015. Pozzolanic activity of elephant grass ash and its influence on the mechanical properties of concrete. Cem. Concr. Compos. 55, 331-336, http://dx.doi.org/10.1016/j.cemconcomp.2014.09.019.

Epstein, E., 1999. Silicon. Annu. Rev. Plant Physiol. Plant Mol. Biol. 50, 641-664, http://dx.doi.org/10.1146/annurev.arplant.50.1.641.

Frías, M., Savastano, H., Villar, E., Sánchez de Rojas, M.I., Santos, S., 2012. Characterization and properties of blended cement matrices containing activated bamboo leaf wastes. Cem. Concr. Compos. 34, 1019-1023, http://dx. doi.org/10.1016/j.cemconcomp.2012.05.005.

IPCC, 2007. International Panel on Climate Change. Climate Change. The Physical Science Basis. Cambridge University Press, Cambridge https://www.ipcc.ch publications and data/publications ipcc fourth assessment report_wg1 report_the_physical_science_basis.htm (accessed 28.07.16).

IRRI International Rice Research Institute. http://irri.org/our-work/research/valueadded-rice/rice-straw-and-husks/ (accessed 28.7.16).

Kanning, R.C., Portella, K.F., Bragança, M.O.G.P., Bonato, M.M., Jeannette, C.M., Dos Santos, J.C.M., 2014. Banana leaves ashes as pozzolan for concrete and mortar of Portland cement. Constr. Build. Mater. 54, 460-465, http://dx.doi.org/10. 1016/j.conbuildmat.2013.12.030.

Ma, J.F., Yamaji, N., 2006. Silicon uptake and accumulation in higher plants. Trends Plant Sci. 11, 392-397, http://dx.doi.org/10.1016/j.tplants.2006.06.007.

Mehta, P.K., 1983. Pozzolanic and Cementitious Byproducts as Mineral Admixtures for Concrete - A Critical Review. American Concrete Institute, ACI Special Publication 79 (46 pages).

Moraes, J.C.B., Akasaki, J.L., Melges, J.L.P., Monzó, J., Borrachero, M.V., Soriano, L., Payá, J., Tashima, M.M., 2015. Assessment of sugar cane straw ash (SCSA) as pozzolanic material in blended Portland cement: microstructural characterization of pastes and mechanical strength of mortars. Constr. Build. Mater. 94,670-677, http://dx.doi.org/10.1016/j.conbuildmat.2015.07.108.

Moraes, J.C.B., Tashima, M.M., Akasaki, J.L., Melges, J.L.P., Monzó, J., Borrachero, M.V., Soriano, L., Payá, J., 2016. Increasing the sustainability of alkali-activated binders: the use of sugar cane straw ash (SCSA). Constr. Build. Mater. 124, 148-154, http://dx.doi.org/10.1016/j.conbuildmat.2016.07.090.
Niu, Y., Tan, H., Wang, X., Liu, Z., Liu, H., Liu, Y., Xu, T., 2010. Study on fusion characteristics of biomass ash. Bioresour. Technol. 101, 9373-9381, http://dx. doi.org/10.1016/j.biortech.2010.06.144.

Pels, J.R., Sarabèr, A.J., 2011. Utilization of biomass ashes. In: Grammelis, P. (Ed.), Solid Biofuels for Energy (series Green Energy and Technology). Springer-Verlag, London, pp. 219-235, http://dx.doi.org/10.1007/978-184996-393-0_10.

Piperno, D.R., 2006. Phytoliths: A Comprehensive Guide for Archaeologists and Paleoecologists. AltaMira Press, Oxford.

Prat, H., 1936. La Systematique des Graminées: Annals des Sciences Naturelles. Series 10. Botanique, Paris.

Prychid, C.J., Rudall, P.J., Gregory, M., 2003. Systematics and biology of silica bodies in monocotyledons. Bot. Rev. 69, 377-440, http://dx.doi.org/10.1663/00068101(2004)069[0377:SABOSB]2.0.CO;2.

Rehman, M.S.U., Umer, M.A., Rashid, N., Kima, I., Han, J., 2013. Sono-assisted sulfuric acid process for economical recovery of fermentable sugars and mesoporous pure silica from rice straw. Ind. Crops Prod. 49, 705-711, http:|/ dx.doi.org/10.1016/j.indcrop.2013.06.034.

Roselló, J., Soriano, L., Santamarina, M.P., Akasaki, J.L., Melges, J.L.P., Payá, J., 2015 Microscopy characterization of silica-rich agrowastes to be used in cement binders: bamboo and sugarcane leaves. Microsc. Microanal. 21, 1314-1326, http://dx.doi.org/10.1017/S1431927615015019.

Schneider, M., Romer, M., Tschudin, M., Bolio, H., 2011. Sustainable cement production-present and future. Cem. Concr. Res. 41, 642-650, http://dx.doi. org/10.1016/j.cemconres.2011.03.019.

Siddique, R., Khan, M.I., 2011. Supplementary cementing materials. Springer-Verlag, Berlin Heidelberg, http://dx.doi.org/10.1007/978-3-64217866-5.

Titiloye, J.O., Bakar, M.S.A., Odetoye, T.E., 2013. Thermochemical characterisation of agricultural wastes from West Africa. Ind. Crops Prod. 47, 199-203, http://dx. doi.org/10.1016/j.indcrop.2013.03.011.

Vassilev, S.V., Baxter, D., Andersen, L.K., Vassileva, C.G., 2010. An overview of the chemical composition of biomass. Fuel 89, 913-933, http://dx.doi.org/10.1016/ j.fuel.2009.10.022.

Vassilev, S.V., Baxter, D., Andersen, L.K., Vassileva, C.G., 2013. An overview of the composition and application of biomass ash. Part 2. Potential utilisation, technological and ecological advantages and challenges. Fuel 105, 19-39, http://dx.doi.org/10.1016/j.fuel.2012.10.001.

Wang, L., Hustad, J.E., Skreiberg, Ø., Skjevrak, G., Grønli, M., 2012. A critical review on additives to reduce ash related operation problems in biomass combustion applications. Energy Procedia 20, 20-29, http://dx.doi.org/10.1016/j.egypro. 2012.03.004.

Wang, Y., Shao, Y., Matovic, M.D., Whalen, J.K., 2014. Recycling of switchgrass combustion ash in cement: characteristics and pozzolanic activity with chemical accelerators. Constr. Build. Mater. 73, 472-478, http://dx.doi.org/10. 1016/j.conbuildmat.2014.09.114.

WBCSD, 2009. Cement Technology Roadmap. World Business Council for Sustainable Development, Geneva, Switzerland, https://www.iea.org/media/ freepublications/technologyroadmaps/cementroadmapreferences.pdf (accessed 28.7.16).

Wilding, L.P., Drees, L.R., 1971. Biogenic opal in Ohio soils. Soil Sci. Soc. Am. Proc. 35 1004-1010, http://dx.doi.org/10.2136/sssaj1971.03615995003500060041x.

Worrell, E., Price, L., Martin, N., Hendriks, C., Ozawa Meida, L, 2001. Carbon dioxide emissions from the global cement industry. Annu. Rev. Energy Environ. 26, 303-329, http://dx.doi.org/10.1146/annurev.energy.26.1.303.

Yuan, Q., Pump, J., Conrad, R., 2014. Straw application in paddy soil enhances methane production also from other carbon sources. Biogeoscience 11 , 237-246, http://dx.doi.org/10.5194/bg-11-237-2014. 